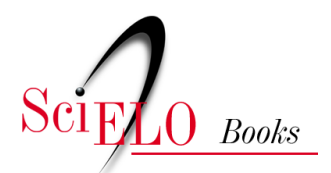

\title{
La teoría desde el Positivismo Lógico, el Pensamiento Crítico y el Pensamiento Complejo
}

\author{
José Enrique Juncosa Blasco \\ Luis Fernando Garcés Velásquez
}

\section{SciELO Books / SciELO Livros / SciELO Libros}

JUNCOSA BLASCO, J. E., and GARCÉS VELÁSQUEZ, L. F. La teoría desde el Positivismo Lógico, el Pensamiento Crítico y el Pensamiento Complejo. In: ¿Qué es la teoría? Enfoques, usos y debates en torno al pensamiento teórico [online]. Quito: Editorial Abya-Yala, 2020, pp. 26-116. ISBN: 978-9978-10-543-6.

http://doi.org/10.7476/9789978105788.0002.

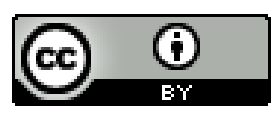

All the contents of this work, except where otherwise noted, is licensed under a Creative Commons Attribution 4.0 International license.

Todo o conteúdo deste trabalho, exceto quando houver ressalva, é publicado sob a licença Creative Commons Atribição 4.0.

Todo el contenido de esta obra, excepto donde se indique lo contrario, está bajo licencia de la licencia Creative Commons Reconocimento 4.0. 


\section{Capítulo I \\ LA TEORÍA DESDE EL POSITIVISMO LÓGICO, EL PENSAMIENTO CRÍTICO Y EL PENSAMIENTO COMPLEJO 5}

\section{Introducción}

Los autores escogidos en este capítulo son representantes y fundadores de tendencias y enfoques que comparten el escenario histórico de la Europa del siglo XX, atravesada por la crisis cultural y del pensamiento propiciada no solo por los horrores de las dos guerras mundiales y la violencia desplegada por los regímenes totalitarios, sino también por los efectos deshumanizantes de la industrialización y el consumo. Estos enfoques, además de coincidir en su intencionalidad crítica, asumen en común dos agendas básicas: la primera de las cuales apunta a desmontar el programa epistémico del positivismo y sus rasgos esenciales: el empirismo (conocemos a partir de los hechos) y la pretensión de un conocimiento objetivo (lo que conocemos a partir de los hechos es totalmente verdadero e inobjetable). El segundo punto de la agenda convergente es la denuncia frontal de los diversos totali-

5 Este capítulo retoma, amplía y profundiza el apartado "Los paradigmas lógicos, críticos y eco-antropológico", del marco teórico de Juncosa, José Enrique. (2006). Teorías del conocimiento en experiencias universitarias con movimientos sociales. Un aporte para la carrera de Antropología Aplicada de la Universidad Politécnica Salesiana. (Tesis de maestría inédita en Desarrollo de la Inteligencia y Educación). Universidad Técnica Particular de Loja, Pontificia Universidad Católica del Ecuador, Ibarra, pp. 31-60. 


\section{6}

tarismos a los que sus autores clave se enfrentaron - el nazismo y el estalinismo, principalmente- mediante un discurso epistemológico que deslegitima cualquier forma o estructura cerrada de pensamiento como la ideología, el dogma o el lenguaje religioso.

El punto de partida de los autores convocados consiste en proponer los compromisos metafísicos, éticos o políticos para luego definir el marco epistemológico a partir del cual, finalmente, establecer las pautas del ejercicio teórico. Tal coincidencia en el itinerario metodológico no quita que los respectivos supuestos y concepciones resulten no solo diversos sino, inclusive, opuestos y polémicos entre sí. Estos autores, escogidos por su potencial y orientación crítica, por la visibilidad de sus huellas en el pensamiento contemporáneo latinoamericano y por su importancia para diversos proyectos políticos actualmente vigentes, son los siguientes:

a. Karl Popper (Viena, 1902-1994) fue el fundador del racionalismo crítico. Aunque algunos lo definen como positivista lógico, debido a la importancia de la empiría a la hora de falsar una teoría, Popper define el conocimiento y las teorías en el contexto del pensamiento deductivo orientado a la solución de problemas teóricos y prácticos. Popper representa muy bien la tendencia contemporánea dominante de la ciencia: el enfoque hipotético-deductivo. El fundamento epistemológico del ejercicio teórico es la negación de cualquier tipo de determinación del pensamiento (histórica, social, política o identitaria) y el correlato sociológico resultante es una sociedad abierta según las expectativas de la concepción liberal, sin dogmas ni sistemas cerrados de pensamiento y, por lo tanto, sin apuestas políticas utópicas o reduccionistas ni sujetas a la hegemonía de sujetos sociales determinados. El escenario de operación y control de la teoría es la lógica de la falsación. 
b. La escuela de Frankfurt, mediante dos de sus representantes: Max Horkheimer (Stuttgart, 1895-1973) y Jürgen Habermas (Düsseldorf, 1929), proporciona una lectura de la teoría a la luz del pensamiento crítico y dialéctico. Basados en la herencia dialéctica marxista, a la que también superan y resignifican, proponen una herramienta de análisis crítico del conocimiento, de la ciencia, de las artes y de las prácticas productivas según su capacidad de transformar las estructuras y el potencial de humanización que comportan. El paradigma crítico está presente en gran parte del ejercicio actual de las ciencias sociales y de la reflexión de los movimientos sociales. En este caso la sociología es el escenario de operación y control del conocimiento y la teoría.

c. Edgar Morin (París, 1921) es el promotor del paradigma del pensamiento complejo. Sobre la base del modelo ecoantropológico, Morin imagina la teoría como un organismo vivo capaz de autoorganización y retroalimentación con su entorno y con otras formas de conocimiento. El pensamiento teórico es un sistema abierto de ideas atravesado por la incertidumbre, que no mutila la totalidad y relaciona dinámicamente los términos excluidos. El escenario de control es el sentido, concebido como un metapunto de vista (ubicado más allá de la teoría) que trasciende la lógica y el lenguaje. Este paradigma es muy vigente y alimenta no pocas apuestas pedagógicas de diversos movimientos sociales e iniciativas de desarrollo que valoran la propuesta de inter y transdisciplinariedad aparejada a la epistemología de Morin.

El presente capítulo sistematiza la lectura y análisis de las obras más relevantes de los autores señalados desde el eje temático de la "teoría” y según las siguientes variables: base paradigmática (compromisos ontológicos y principios fundamentales), rasgos del conocimiento derivados, metateoría, procesos teóricos fundamentales, perfil del teórico, escenario de acción de la teoría y, por último, escenarios de control 
de la teoría. Finalmente, concluimos con la propuesta de algunas y muy breves implicaciones para la investigación. La Tabla 1 proporciona una visión comparativa de las características distintivas de cada uno de los enfoques que serán descritos a continuación.

\author{
Tabla 1 \\ La teoría según el positivismo lógico, \\ el pensamiento crítico-dialéctico y el pensamiento complejo
}

\begin{tabular}{|c|c|c|c|}
\hline \multirow{3}{*}{$\begin{array}{l}\text { Variables } \\
\text { de análisis }\end{array}$} & \multicolumn{3}{|c|}{ ENFOQUES METATEÓRICOS BÁSICOS } \\
\hline & Positivismo lógico & $\begin{array}{c}\text { Pensamiento } \\
\text { crítico-dialéctico }\end{array}$ & Pensamiento complejo \\
\hline & $\begin{array}{l}\text { Karl Popper } \\
(1902-1994)\end{array}$ & $\begin{array}{c}\text { Max Horkheimer } \\
(1895-1973) \\
\text { Jürgen Habermas (1926) }\end{array}$ & Edgar Morin (1921) \\
\hline $\begin{array}{l}\text { Compromisos } \\
\text { ontológicos } \\
\text { o base } \\
\text { paradigmática }\end{array}$ & $\begin{array}{l}\text { Carácter abierto del } \\
\text { tiempo. Historia sin } \\
\text { finalidad y sin utopías. } \\
\text { La realidad es indeter- } \\
\text { minada y cognoscible. }\end{array}$ & $\begin{array}{l}\text { La realidad no es dada } \\
\text { sino construida por las } \\
\text { relaciones. } \\
\text { La historia tiene un fin: } \\
\text { la humanización o la } \\
\text { emancipación. }\end{array}$ & $\begin{array}{l}\text { Carácter complejo de la } \\
\text { vida: autoorganización, } \\
\text { retroalimentación y } \\
\text { retroacción. } \\
\text { El sentido no está en la } \\
\text { historia. Es añadido por } \\
\text { los humanos. }\end{array}$ \\
\hline $\begin{array}{l}\text { Rasgos del } \\
\text { conocimiento }\end{array}$ & $\begin{array}{l}\text { El conocimiento funcio- } \\
\text { na como el tiempo y la } \\
\text { historia: es abierto y sin } \\
\text { determinaciones. } \\
\text { Conocimiento sin } \\
\text { subjetividad. } \\
\text { Pensamiento para la } \\
\text { solución de problemas: } \\
\text { mejora la estructura. } \\
\text { Pensar es conjeturar. } \\
\text { Pensamiento abierto. }\end{array}$ & $\begin{array}{l}\text { El conocimiento funciona } \\
\text { como la sociedad. Es pro- } \\
\text { ducto de la praxis social; } \\
\text { expresa sus relaciones. } \\
\text { Monitorea la marcha de } \\
\text { la historia: compara el ser } \\
\text { con el deber ser. } \\
\text { Pensamiento dialéctico } \\
\text { que trasciende la solución } \\
\text { de problemas y el funcio- } \\
\text { namiento de la estructura. } \\
\text { Pensar es cuestionar lo dado. } \\
\text { Pensamiento crítico. }\end{array}$ & $\begin{array}{l}\text { El conocimiento fun- } \\
\text { ciona como los seres } \\
\text { vivos (isomorfismo } \\
\text { vida-pensamiento). } \\
\text { El conocimiento relaciona } \\
\text { las cosas más allá de la } \\
\text { lógica de oposición. }\end{array}$ \\
\hline $\begin{array}{l}\text { Concepción } \\
\text { metateórica }\end{array}$ & $\begin{array}{l}\text { La teoría es un mecanis- } \\
\text { mo adaptativo diverso al } \\
\text { genético y conductual. } \\
\text { Mecanismo abierto y } \\
\text { acumulativo de solución } \\
\text { de problemas. } \\
\text { Rasgos esenciales: falsa- } \\
\text { ble y refutable. }\end{array}$ & $\begin{array}{l}\text { Teoría como praxis social. } \\
\text { Teoría crítica: devela } \\
\text { la enajenación del pre- } \\
\text { sente. Al servicio de la } \\
\text { emancipación. } \\
\text { Versus teoría tradicional } \\
\text { que considera la realidad } \\
\text { como dada. }\end{array}$ & $\begin{array}{l}\text { La teoría es como un } \\
\text { organismo vivo, pero de la } \\
\text { noosfera. } \\
\text { Forma de idea abierta: } \\
\text { versus dogma e ideología. } \\
\text { Compleja: interrelaciona } \\
\text { lo diverso. }\end{array}$ \\
\hline
\end{tabular}




\begin{tabular}{|c|c|c|c|}
\hline \multirow{3}{*}{$\begin{array}{l}\text { Variables } \\
\text { de análisis }\end{array}$} & \multicolumn{3}{|c|}{ ENFOQUES METATEÓRICOS BÁSICOS } \\
\hline & Positivismo lógico & $\begin{array}{l}\text { Pensamiento } \\
\text { crítico-dialéctico }\end{array}$ & Pensamiento complejo \\
\hline & $\begin{array}{l}\text { Karl Popper } \\
(1902-1994)\end{array}$ & $\begin{array}{c}\text { Max Horkheimer } \\
(1895-1973) \\
\text { Jürgen Habermas (1926) }\end{array}$ & Edgar Morin (1921) \\
\hline Procesos teóricos & $\begin{array}{l}\text { Planteamiento del } \\
\text { problema, conjetura } \\
\text { (teoría), falsación y } \\
\text { refutación. }\end{array}$ & $\begin{array}{l}\text { Identificar el contexto so- } \\
\text { cial e histórico de la teoría. } \\
\text { Identificar la praxis social } \\
\text { subyacente. }\end{array}$ & $\begin{array}{l}\text { Núcleo y cinturón } \\
\text { protector. } \\
\text { Interdisciplinariedad, } \\
\text { transdisciplinariedad, } \\
\text { paradigmas. }\end{array}$ \\
\hline Perfil del teórico & $\begin{array}{l}\text { Apóstol de la sociedad } \\
\text { abierta. Combate dog- } \\
\text { mas y sistemas cerrados } \\
\text { de pensamiento. Solu- } \\
\text { ciona problemas prácti- } \\
\text { cos y aplicados. }\end{array}$ & $\begin{array}{l}\text { Vigilante anticipador de la } \\
\text { marcha de los movimien- } \\
\text { tos sociales hacia la eman- } \\
\text { cipación. Cuestionador } \\
\text { de sistemas de acción y } \\
\text { pensamiento deshumani- } \\
\text { zantes y hegemónicos. }\end{array}$ & $\begin{array}{l}\text { Articulador de las vertien- } \\
\text { tes humanista y técnica del } \\
\text { conocimiento. Identifica- } \\
\text { dor de paradigmas y for- } \\
\text { mas de pensar antes que de } \\
\text { contenidos. Relacionador } \\
\text { del conocimiento teórico } \\
\text { con otras formas (el mito, } \\
\text { las creencias, el arte). }\end{array}$ \\
\hline $\begin{array}{l}\text { Escenarios } \\
\text { de acción }\end{array}$ & $\begin{array}{l}\text { La ciencia y la academia. } \\
\text { Reingeniería social. }\end{array}$ & $\begin{array}{l}\text { La política y las luchas } \\
\text { sociales. }\end{array}$ & $\begin{array}{l}\text { La educación formal e } \\
\text { informal. }\end{array}$ \\
\hline $\begin{array}{l}\text { Escenarios } \\
\text { de control }\end{array}$ & $\begin{array}{l}\text { La lógica: procesos lógi- } \\
\text { cos de falsación; apli- } \\
\text { cación y capacidad de } \\
\text { solución de problemas. }\end{array}$ & $\begin{array}{l}\text { La sociología; las utopías } \\
\text { emancipatorias. }\end{array}$ & $\begin{array}{l}\text { Metapunto de vista } \\
\text { respecto a la lógica y el } \\
\text { lenguaje: el sentido. }\end{array}$ \\
\hline
\end{tabular}

Elaboración de los autores.

\section{Conocimiento y metateoría según el racionalismo crítico de Karl Popper}

Karl Popper (Viena, 1902 - Londres, 1994) fue profesor de la London School of Economics ${ }^{6}$. Formó parte de numerosas academias científicas y recibió varios doctorados honoris causa. Al haber

6 Nació en el seno de una familia judía conversa al protestantismo. En 1937, tras el ascenso del nazismo, abandonó Viena y se trasladó primero a Australia y luego a Inglaterra, donde ejerció la etapa más productiva de su vida intelectual. En 1982 recibió de la reina Isabel II de Inglaterra el título nobiliario de Sir. 
sido uno de los epistemólogos más prestigiosos e influyentes del siglo XX, es un referente obligado e inexcusable para profundizar los procedimientos y alcances de la teoría. Víctima del nazismo, cultivó un rechazo profundo a las formas cerradas del pensamiento. Como creyente, asumió la perspectiva del teólogo protestante Karl Barth (1886-1968) para dar forma a su idea de pensar sin determinismos, a partir de un universo abierto y un mundo sin historia a total disposición de la libertad humana.

La obra que condensa su propuesta epistemológica es Lógica de la investigación cientifica (1934, 1973 b para una de sus ediciones en español) cuya tesis esencial se expresa en la siguiente proposición: "pensar es conjeturar"; es decir, pensar consiste en la capacidad de plantear respuestas anticipadas a problemas prácticos o teóricos, respuestas no irrefutables sino falsables, abiertas y disponibles a que la realidad tarde o temprano las pueda deslegitimar. Esta idea madre fue desarrollada posteriormente en múltiples conferencias y artículos. Los presupuestos ontológicos y políticos implicados en la tesis se pueden encontrar, además, en obras como La miseria del historicismo (1973a), El universo abierto. Un argumento a favor del indeterminismo (1994), El mito del marco común. En defensa de la ciencia y la racionalidad (2005) y La sociedad abierta y sus enemigos (2006).

Su actitud polémica apuntó contra varios frentes a la vez, todos ellos caracterizados por plantear algún tipo de determinismo respecto al conocimiento: contra el neopositivismo lógico del denominado Círculo de Viena del que formó parte, por condicionar el pensamiento a los mecanismos de inferencia inductiva; contra Freud y los defensores del psicoanálisis, por el determinismo del inconsciente sobre el pensamiento; contra el pensamiento dialéctico de Hegel y de Marx, por el determinismo histórico que los fundamenta. Contra los miembros de la escuela de Frankfurt lo animó una agria dispu- 
ta pública, en especial con Jürgen Habermas. De esta escuela llegó a afirmar, incluso, que "tan solo genera quejas y oscuros gritos de Casandra acerca de los malos tiempos en que vivimos y acerca de la perversión de la cultura burguesa”.

\section{Compromisos ontológicos, éticos y políticos}

A diferencia de otras posiciones, Popper hace de la cosmología el fundamento y el punto de partida de su epistemología y metateoría: "Mi argumentación, pues será más en un plano cosmológico: hablaré del carácter de nuestro mundo en vez de hablar del significado de las palabras" (1994, p. 23); por lo tanto, ni la sociología ni los análisis filosóficos en torno al lenguaje pueden ser puntos de partida válidos desde los cuales establecer los parámetros y alcances del conocimiento. La primera afirmación básica sobre el mundo se refiere al tiempo y consiste en su carácter abierto e impredecible, imposible de ser capturado por el pensamiento, ya sea bajo la forma de algún sentido o finalidad de la historia o a partir de la capacidad de predicción causal que se atribuye a las leyes.

Respecto al sentido de la historia, nada autoriza a pensar en su existencia previa más allá de los significados que nosotros podamos construir en ella ${ }^{8}$ ( $c f r$. infra); pero, en rigor, la historia carece de sentido. Las leyes científicas pueden establecer sistemas de predicción causal según reglas propias del pensamiento, pero no están en condiciones de anticipar el devenir del mundo, de autorizar miradas

7 Conversación sostenida con Marcuse en un programa de radio de la $B B C$ de Londres. Citada en http://cibernous.com/autores/popper2/teoria/biografia.html

8 En este aspecto interpreta epistemológicamente el punto de vista del teólogo protestante Karl Barth, según el cual cualquier trama de la historia funciona como pretendido marco común que exime al individuo de tomar decisiones y lo enajena de la posibilidad de responder a la fe desde su libertad. Ver Popper (2005, pp. 163 y ss.). 
proféticas, emancipatorias o identificar alguna trama en la historia que se constituya en un marco común para todos. Si las leyes científicas son deterministas en sus procedimientos, no podemos afirmar lo mismo del mundo y la historia cuya impredecibilidad parece ser su carácter esencial.

La unicidad del mundo respecto al conocimiento es el segundo rasgo de su cosmología que explica la tensión que predispone a las teorías hacia nuevos y cada vez mejores niveles de aproximación a la verdad y universalidad. El mundo tiene una sola calidad respecto al conocimiento, ya que todo él es virtualmente cognoscible, aun a pesar de su indeterminismo y de la imposibilidad real de lograrlo: "en este sentido del conocimiento, todo nuestro conocimiento se refiere solo a este único mundo nuestro y a ningún otro" (1994, p. 71). En este punto, es oportuno destacar su deslinde de la dualidad kantiana del mundo respecto al conocimiento expresada en las categorías de fenómeno (lo que puedo conocer) y noúmeno (lo que no puedo conocer).

La consecuencia para la conducta, la política y el pensamiento de los rasgos cosmológicos esenciales señalados, la impredecibilidad y unicidad del mundo respecto al conocimiento, es obvia: no existe nada que determine el pensamiento ni la psique ni las realidades físicas ni la historia. El correlato político de tal concepción es el proyecto de una sociedad abierta: a un universo abierto corresponde una sociedad abierta y democrática fundada en dispositivos teóricos considerados mecanismos también abiertos. Tal proyecto tiene un protagonista fundamental: el intelectual, quien debe combatir cualquier forma de visión determinista porque toda determinación innecesaria del pensamiento clausura su apertura ( $c f r$. supra). Desde esta trinchera, la batalla más dura se libra contra el determinismo cientí- 
fico', el enemigo más difícil de vencer, aun más que los determinismos religiosos y metafísicos, porque sus argumentos no adolecen de la debilidad de estos.

En última instancia, el programa epistemológico de Popper reivindica un proyecto ético y político fundado en la libertad absoluta en el cual el ejercicio del pensamiento libre de ataduras es más importante que la reflexión explícita sobre la moral y la ética, ámbitos proclives a deslizarse por diversos determinismos. Si en un momento se distanció del dualismo kantiano porque considera inaceptable la existencia de diversas realidades, una que podemos conocer y otra imposible de ser conocida, recupera y restaura en cambio el proyecto kantiano de racionalidad iluminista porque lo considera una herramienta útil para superar formas cerradas y violentas de pensar. La racionalidad libre es el instrumento y el fundamento capaz de

evaluar razones o argumentos, en pro o en contra de enunciados de hecho, o teorías científicas [...] Si disfrutamos de este tipo de libertad, es posible que disfrutemos también de la libertad de crear, de razonar y de deducir en los aspectos morales, y de disfrutar de la responsabilidad que acompaña a la creación y a la elección. (1994, pp. 135-136)

\section{La metateoría popperiana}

A partir de la cosmología descrita, la reflexión metateórica de Popper consta de tres aspectos muy integrados que separamos para

9 Según Popper, el determinismo científico es "la doctrina que dice que el estado de cualquier sistema físico cerrado en cualquier instante futuro dado puede ser predicho, incluso desde dentro del sistema, con cualquiera que sea el grado estipulado de precisión, mediante la deducción de la predicción a partir de teorías, en conjunción con condiciones iniciales cuyo grado de precisión requerido puede calcularse siempre... si la tarea de predicción es dada" (1994, p. 59). 
facilitar su comprensión: 1. las teorías en el contexto de la concepción de los tres mundos; 2 . la teoría, dispositivo de un mecanismo adaptativo: el conocimiento científico; 3. la teoría considerada dispositivo conjetural que aspira a la verdad.

\section{Las teorías: objetos y realidades del Mundo 3}

La metafísica popperiana decanta en la teoría de los tres mundos, la cual, a su vez, se constituye en el fundamento cosmológico de su "filosofía pluralista" que se distancia de otras cosmologías y teorías del conocimiento monistas o dualistas, cabalmente porque estas últimas producen visiones deterministas de la sociedad y de la existencia.

Su punto de partida consiste en reinterpretar el mundo de las ideas de Platón y advertir que la tradición había englobado erróneamente en el mundo de las ideas tanto los actos mentales (aprehensión, comprensión) cuanto sus subproductos (conceptos, teorías, argumentos). De la mano de lógico y matemático alemán Gottlob Frege (1848-1925) establece una lectura creativa e innovadora de la epistemología platónica al distinguir y separar los actos mentales de las ideas producidas por esos mismos actos, entre las operaciones intelectuales y los instrumentos del conocimiento como objetos y habitantes de dos mundos diversos. Estructura así, la teoría de los tres mundos: el Mundo 1 (M1) o de la realidad física, el Mundo 2 (M2) o de los estados y las operaciones mentales, y el Mundo 3 (M3) o el de las realidades del lenguaje y de los contenidos o ideas; mundos irreductibles entre sí que gozan de una relativa autonomía, a la vez que se vinculan mutuamente según relaciones específicas. La Figura 1 sistematiza las características esenciales de los seres de cada uno de los tres mundos y sus relaciones. 


\section{5}

Figura 1

Los tres mundos según Karl Popper ${ }^{10}$

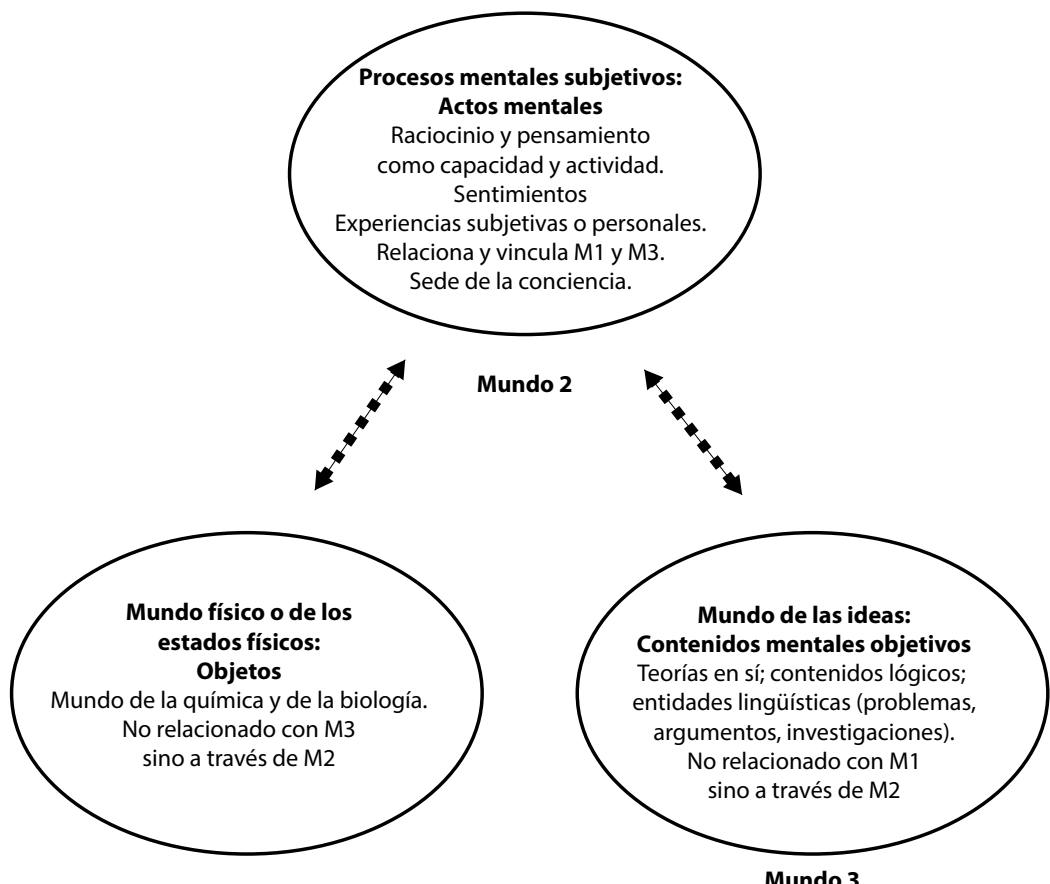

Mundo 1

Mundo 3

Elaboración de los autores.

10 Elaboración de los autores a partir de la versión ampliada de una de sus conferencias de 1968: "Una teoría objetiva de la comprensión histórica" ([1968] 1990, pp. 209 y ss.). También ver su "Post Scriptum a la lógica de la investigación científica”, en El Universo abierto. Un argumento a favor del indeterminismo, vol. II (Popper, 1994, pp. 64 y ss.) Algunas de las conferencias reunidas en La responsabilidad de vivir (1995) también son claves para determinar las relaciones entre los mundos popperianos y para comprender la conciencia como realidad del M2 al mismo tiempo que producto de la relación con M1 y M2. Para una caracterización del M3, ver "Epistemología sin sujeto cognoscente", ponencia dictada en 1967 (Estany, A., 2001). 


\section{6}

El M1 es el mundo de los estados físicos, de los objetos y realidades químicas y biológicas. El M3 es abstracto y es el más complejo de todos. Allí habitan los contenidos mentales objetivos. Es el mundo del conocimiento humano que posee una historia, que incluye al que ha sido formulado lingüísticamente como al que no ha sido formulado todavía. Como parte integrante del universo del discurso, las realidades del M3 poseen el carácter objetivo de verdad o falsedad en tanto que los estados de la conciencia (M2) podrán ser catalogados de subjetivamente sinceros o insinceros. Las obras de arte y los productos culturales (una ópera, una película) también integran el M3, del que también forman parte realidades híbridas, como los libros y las bibliotecas que son, al mismo tiempo y en tanto objetos físicos, parte del M1. El M2 es la sede de la conciencia, de la subjetividad y de los sentimientos, así como de las capacidades y operaciones intelectuales, no de los contenidos ni de los productos de estas (M3).

Las relaciones entre los mundos se caracterizan por la causalidad, la relativa autonomía y la mutua apertura. Como se observa en el esquema, el M2 es el único que se relaciona con los otros dos mundos; el M1 se relaciona con el M3 y viceversa, solo por medio del M2. El primer tipo de estas relaciones es causal, de tal modo que la apertura causal del Mundo 1 hacia el Mundo 2 y la mutua apertura causal entre el Mundo 2 y el Mundo 3 persigue también crear espacios para la libertad (Popper, 1994, p. 137). En efecto, es la irreductibilidad y mutua apertura de estos mundos la que previene contra cualquier reduccionismo que pretenda hacer de uno de ellos una realidad derivada de cualquiera de los otros dos o concebir el conocimiento como subproducto del mundo físico (M1), de la mente (M2) o del lenguaje (M3).

En tal sentido, el esquema solicita una serie de precisiones respecto al M3, la más importante de las cuales consiste en que, si bien 
es producido por el M2, sus objetos, en cambio, son productos no intencionados y no planificados del M2, es decir, autónomos, con una enorme capacidad de generar realidades en el M1, así como estados del $\mathrm{M}^{11}$. Por lo tanto, los objetos del M3 no son meros instrumentos sino realidades producidas y productoras, a la vez, de otras realidades. Así, las teorías, seres privilegiados del M3, no son simplemente constructos mentales o meros instrumentos ya que están doblemente orientadas hacia la realidad y hacia la objetividad lógica: "su verdad y falsedad dependen enteramente de su relación con el 'Mundo 1', una relación que... no podemos alterar. Su verdad o falsedad dependen de la estructura interna del 'Mundo 3' (especialmente el lenguaje) y del 'Mundo 1', el último de los cuales... es el patrón mismo de la realidad" (1994, p. 143). Debido a que la relación entre M3 y M1 es mediada, las teorías no tienen una relación directa con el mundo. Con ello, hecha por tierra el postulado positivista según el cual los conceptos, teorías y leyes científicas son abstracciones de hechos reales y constituyen algo así como copias del mundo, y anula su pretensión de que, efectivamente, las teorías copian o expresan la realidad. Los mundos se vinculan entre sí también mediante relaciones de carácter genético que configuran un itinerario evolutivo de humanización creciente que arranca con el M1 (el mundo físico), continúa con los sentimientos animales propios del M2 y culmina en el M3 con la aparición del lenguaje.

11 “Trataré de mostrar que tenemos que admitir la existencia de una parte autónoma del 'Mundo 3'; una parte que consiste en los contenidos de pensamiento objetivos que son independientes, y claramente diferenciables de los procesos de pensamiento subjetivos o personales por medio de los cuales son captados y en cuya captación influyen causalmente. Afirmo así que existen objetos autónomos del 'Mundo 3' que no han tomado aún una forma propia del 'Mundo 1' ni del 'Mundo 2', pero que, no obstante, interactúan con nuestros procesos de pensamiento. De hecho, influyen decisivamente en nuestros procesos de pensamiento" (Popper, 1994, p. 141). 
Vale la pena aquí adelantar la crítica a la teoría de los tres mundos respecto a la lectura despectiva del M2, al que Popper califica de "fango segundo mundano"12, percibido apenas como mediador, sumido en la subjetividad y la inconsistencia emocional. Si su propuesta de conocimiento y de ciencia se enraíza en la objetividad, atributo del M3, único lugar donde florece la "buena ciencia", la racionalidad popperiana excluiría toda forma de subjetividad, tanto en su expresión individual como colectiva (el "nosotros"). Por lo tanto, la teoría del M3 busca construir una epistemología "sin sujeto cognoscente" (Popper, 2001, pp. 138 y ss.) antagónica a las tesis psicologistas, a la sociología del conocimiento y a las actuales posturas que revindican y recuperan la subjetividad y las pertenencias identitarias en la práctica científica. Para la epistemología sin sujeto son irrelevantes las pertenencias de género, culturales o sociales, pues todos deben contribuir como obreros genéricos a acrecentar el conocimiento objetivo.

\section{Las teorías: dispositivos de un mecanismo adaptativo}

Desde un punto de vista biológico evolutivo ${ }^{13}$, Popper identifica tres mecanismos adaptativos de los organismos: el mecanismo genético, el conductual y el conocimiento científico; este último, una especialización muy desarrollada de los mecanismos biológicos. Los mecanismos genéticos se caracterizan por responder a un desequilibrio o problema mediante el despliegue de dispositivos de eliminación y selección natural según los cuales una transformación no programada

12 Tal expresión respecto al M2 consta en otro de sus ensayos que no hemos revisado: Conocimiento objetivo (1974, pp. 148 y ss., citado en Datri et al., 2004, p. 104).

13 Ver sus conferencias recopiladas en La responsabilidad de vivir. Escritos sobre politica, historia y conocimiento ([1972] 1995, pp. 17 y ss.) y El mito del marco común. En defensa de la ciencia y la racionalidad ([1975] 2005, pp. 17 y ss.). 
pero adaptada pervive en tanto que los individuos en el que aparece un cambio genético no adaptado desaparecen por no poder sobrevivir. De manera análoga, los mecanismos conductuales responden a los desequilibrios por criterios de ensayo y error no orientados, eliminando aleatoriamente las conductas no adaptadas e incorporando aquellas que de manera casual resultan eficaces. Las transformaciones genéticas o conductuales se incorporan a los organismos y forman parte de él, por transmisión genética en el primer caso o mediante procesos de transmisión cultural o imitación, en el segundo.

El conocimiento opera en todos los organismos (humanos y no humanos), merced al mismo procedimiento de ensayo y error común a los otros mecanismos adaptativos, según el siguiente esquema de tres fases: surgimiento de un problema, intentos de solución y eliminación (Popper, 1995, pp. 22 y ss.). La teoría es el dispositivo más importante del conocimiento y, a diferencia de los mecanismos genéticos y conductuales, no incorpora las transformaciones a los organismos ni al sistema genético, haciendo posible su fluida asimilación o eliminación. Por no estar incorporadas al organismo y contar con una existencia relativamente autónoma, la función eliminatoria de la teoría no es violenta porque es posible descartar, anular o subsumir una teoría en otra sin necesidad de eliminar a los individuos, lo que no ocurre con las transformaciones genéticas o conductuales cuyas funciones eliminatorias son violentas.

Actúa al son de un aparato racional en el que las transformaciones son evaluadas primero y asimiladas luego de ser sometidas a un aparato crítico. La teoría también produce adaptaciones porque busca solucionar problemas desde un punto de vista crítico, no casual (como el sistema genético) ni aleatorio (como el conductual). Además, este dispositivo es abierto ya que la solución de un problema implica la aparición de otros en un horizonte ilimitado y progre- 
sivo, a diferencia de las transformaciones genéticas y conductuales que son realidades orgánicas cerradas y clausuradas en sí mismas.

Las teorías son dispositivos que abrazan todo el pensamiento y, por lo tanto, no son sistemas especializados que se desarrollan exclusivamente en el escenario de la ciencia, sino también de la vida cotidiana, ya que comparten los principios que rigen el pensamiento ordinario. Las teorías actúan científicamente, en cambio, porque: a) Se ejercen en un marco de posibilidad en tanto que los mecanismos genético y conductual reaccionan solo ante cambios reales; b) A diferencia de como ocurre en el pensamiento ordinario, las teorías científicas son conjeturas, no certezas; a la vez, forman parte de marcos lógicos y críticos que permiten identificar nuevos problemas, teóricos y prácticos, en las conjeturas producidas.

Desde dicho enfoque, el carácter público de las teorías, es decir, el que deban formularse lingüísticamente y comunicarse públicamente es esencial para convertirse en objetos exteriores abiertos a la investigación y a la crítica. Si hay batallas que valen la pena, estas son las teóricas ya que al ser libradas en los foros académicos solo eliminan ideas y no personas.

\section{Las teorias: redes e instrumentos para la solución de problemas. El método deductivo de contrastar}

Hasta aquí, las teorías han sido consideradas realidades autónomas del M3; al mismo tiempo, han sido definidas como la expresión más evolucionada de un sistema adaptativo: el conocimiento. Sin embargo, el punto de vista más desarrollado es el funcional a partir del cual Popper desarrolla el proceso de conocimiento teórico y en cuyo contexto concibe las teorías no solo como instrumentos del conocimiento sino también como aproximaciones sucesivas en 
nuestra búsqueda de la verdad, "en nuestra búsqueda de soluciones cada vez mejores a problemas cada vez más profundos (donde 'cada vez mejores' significa... 'más próximos a la verdad')” (Popper, 2005, p. 192). En tanto aproximación perfectible, la universalidad de las teorías es un producto, un logro final y meta, nunca un punto de partida. Es el resultado de un proceso continuo de aproximaciones en el cual a mayor universalidad mayor aproximación.

Es en este punto donde la elocuente metáfora de la red abre nuevos significados para entender la teoría como punto inicial de un proceso de conocimiento enfocado a la solución de problemas:

Yo considero nuestras teorías científicas como invenciones humanas, redes creadas por nosotros para atrapar el mundo. Por supuesto, estas difieren de las invenciones de los poetas e incluso de las de los técnicos. Las teorías no son solo instrumentos. A lo que aspiramos es a la verdad: contrastamos nuestras teorías con la esperanza de eliminar las que no son verdad. De esta manera podemos conseguir nuestro propósito de perfeccionar nuestras teorías; incluso como instrumentos: haciendo redes que estén cada vez mejor adaptadas para capturar nuestro pescado, el mundo real. Sin embargo, nunca serán instrumentos perfectos para ese propósito. Son redes racionales hechas por nosotros mismos, y no deben confundirse con una representación completa del mundo real en todos sus aspectos, ni siquiera aunque tengan un gran éxito; ni siquiera aunque parezcan producir excelentes aproximaciones a la realidad. (Popper, 1994, p. 65)

¿Cómo funciona esta red? La teoría es una forma de representación de la realidad o del sistema por medio de un modelo simplificador (pp. 67 y ss.), cuya función es reducir al máximo la complejidad del mundo para iluminar (atrapar) solo lo pertinente de él, aquello que se quiere explicar y dar razón (predecir). En rigor las teorías no constituyen una representación completa del mundo sino una aproximación instrumental; por lo tanto, ni su simplicidad ni su 
complejidad ni su determinismo lógico son rasgos del mundo, sino de las teorías. Un modelo teórico, entonces, es una red que incluye, excluye y predice en un campo limitado de la realidad. Para ello, son preferibles las teorías simples porque cumplen mejor su tarea de red y, además, resultan mejor contrastables respecto a la realidad y las aplicaciones que las complejas.

Para definir el ciclo de operaciones y procedimientos asociados con la teoría Popper se desentiende de la perspectiva positivista basado en la inducción, proceso inferencial que procede de lo particular a lo universal, de la experiencia y la observación al concepto, y que hace de la teoría el resultado de la generalización de los datos. Su procedimiento se basa, en cambio, en la deducción, que procede de manera inversa; es decir, de lo general a lo particular (del concepto, teoría o hipótesis a la experiencia) como única forma de inferencia capaz de producir conocimiento (Popper, 1973, pp. 27-47) y explicar causalmente la realidad: "Dar una explicación causal de un evento significa el deducir un enunciado que lo describe, usando como premisas de la deducción una o más leyes universales, junto con ciertos enunciados singulares, las condiciones iniciales" (pp. 27-47).

Su crítica al rol y los alcances de la inducción cava una zanja que lo separa radicalmente de todas las formas de positivismo y, especialmente, del neopositivismo de la escuela de Viena, por dos razones fundamentales: la negación del rol esencial de la formulación del problema en la investigación y la negación de la carga teórica del dato. En efecto, el conocimiento teórico no nace de la observación tal como pretenden los positivistas, quienes mutilan la totalidad del proceso investigativo al excluir del ciclo el problema inicial y los interrogantes que condicionan la mirada de la realidad. Popper no desconoce el rol de la observación, pero la reubica en una fase posterior y la integra en un proceso más amplio de resolución de problemas. 
Además, el neopositivismo desconoce que "todas las observaciones están impregnadas de teoría. No hay observación pura, desinteresada, libre de teoría" (2005, p. 28). En este sentido, las teorías funcionan como órganos sensoriales y nuestros órganos sensibles, como teorías. Tal postura deja insubsistente, incluso, la concepción axiomática de la teoría que distingue en su interior dos tipos de afirmaciones o proposiciones: las teóricas (abstractas) y las observacionales (aplicadas a la realidad) (ver infra) ya que estas últimas también están cargadas de teoría.

La inducción, por tanto, no solo resulta superflua; además, enturbia el problema epistemológico y ni siquiera es fuente de probabilidad. A este método, el inductivo, Popper opone lo que él denomina el método deductivo de contrastar, mediante el cual una hipótesis o teoría puede contrastarse empíricamente después de que ha sido formulada. Los pasos del proceso de conocimiento deductivo, en un sentido más amplio, son los siguientes (2005, pp. 196 y ss.): 1. Seleccionamos un problema, quizá por haber tropezado con él; 2 . Tratamos de resolverlo proponiendo una teoría como solución tentativa; 3. Mediante la discusión crítica de nuestras teorías, nuestro conocimiento se desarrolla por medio de la eliminación de algunos errores, y de esta manera aprendemos a comprender nuestros problemas y nuestras teorías, así como la necesidad de obtener nuevas soluciones; 4. La discusión crítica incluso de nuestras mejores teorías siempre saca a luz nuevos problemas. En cuatro palabras, el proceso se resume así: problemas - teorías - crítica - problemas. Si bien todo conocimiento procede de esta forma, la característica del proceder científico es la eliminación de errores por medio de la crítica y discusión de las teorías.

En un plano más específico y detallado, las operaciones y productos mentales y proposicionales del método deductivo de contrastar son los siguientes: 
a. Identificación del problema teórico o práctico que emerge de la realidad o de las mismas teorías.

b. Creación de teorías e hipótesis (hipotizar). Son explicaciones anticipadas que surgen a partir de los problemas teóricos o prácticos identificados, o según procesos creativos intuitivos, de tal modo que no existen procedimientos lógicos que aseguren el modo adecuado de "inventarlas".

c. Extracción de las conclusiones de la teoría o hipótesis según procesos deductivos cuyo resultado son proposiciones que establecen conexiones de la teoría con aplicaciones prácticas o realidades experimentales.

d. Contrastación según cuatro procedimientos. 1. Comparación lógica de una conclusión con otra (coherencia interna del sistema); 2. Estudio de la forma lógica de la teoría o hipótesis para determinar si la teoría es empírica o tautológica; 3. Comparación de la teoría con otra(s) teoría(s) para determinar si se trata de un avance científico; 4. Contrastación empírica de las conclusiones o enunciados singulares que se deducen de la teoría, en relación con la práctica, a la realidad experimental o a las posibles aplicaciones. Si las conclusiones han sido verificadas por la práctica, han sido verificadas por esta ocasión y no las desechamos (por ahora). Si las conclusiones han sido desmentidas por la práctica, esto es, que han sido falsadas, se deduce que la teoría que les ha dado origen también es falsa.

Los principios del conocimiento científico son comunes a todas las ciencias y se alinean en un sistema autopropulsor (2005, p. 177) basado en el mecanismo de la hipótesis y la conjetura (P1-TT-DC-P2), en el que P1 (problema inicial, teórico o aplicado), TT (teoría tentativa), DC (discusiones críticas), P2 (resultados formulados como nuevos problemas) se vinculan 
circularmente de uno a otro en un movimiento sin fin. Este mecanismo instaura una ley de movimiento según la cual es posible iniciar por cualquiera de los términos del ciclo conjetural y no necesariamente por el problema, pero Popper propone la actitud socrática del ciclo abierto que inicia con un problema y culmina con otro (2005, p. 177) para dar cuenta de la fecundidad irrefrenable de la ciencia. Por tanto, se parte de problemas, se acude luego a la teoría y al análisis crítico para iluminar respuestas anticipadas y las conclusiones obtenidas son (o deberían ser) falsables y dispuestas a ser desbancadas por futuras y mejores conclusiones.

La Figura 2 resume las diferencias entre el procedimiento inductivo, que coloca la observación en primer lugar y luego la teoría como resultado final de la generalización de los datos, y el deductivo propuesto por Popper, cuyo proceso investigativo inicia con el planteamiento del problema y la teoría, implícita en la hipótesis que lo ilumina.

Figura 2

Proceso inductivo y deductivo y lugar de la teoría
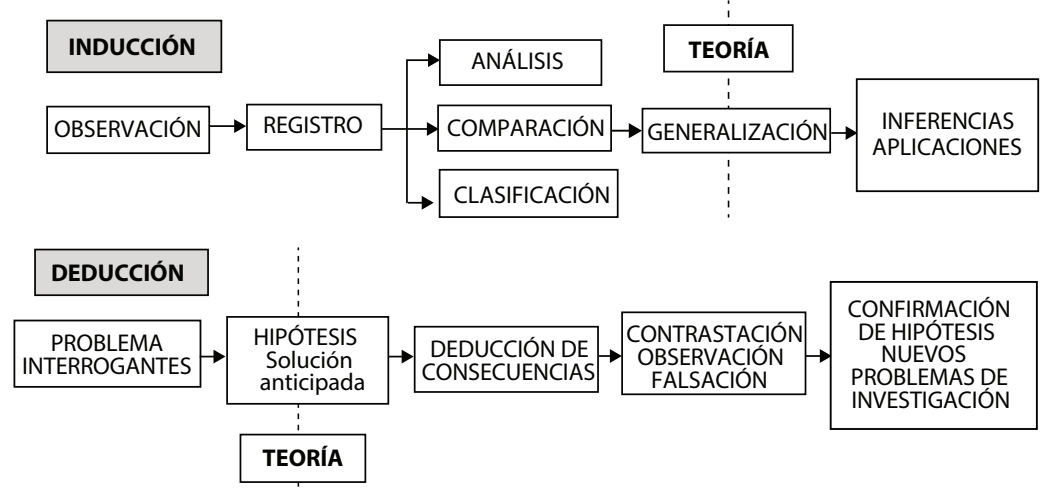

Elaboración de los autores a partir de Pardo (1998, p. 74). 
La hipótesis y la falsación son criterios metodológicos de demarcación que, por un lado, homologan todos los tipos de conocimiento científico a pesar de referirse a distintos ámbitos de la realidad; por otro, esos criterios distinguen la ciencia de otros tipos de conocimiento. Popper propone la unidad de las ciencias porque todas responden al mismo paradigma hipotético, trasfondo común para todas las ciencias, superando así el paradigma que separa drásticamente la historia (las humanidades) de las ciencias naturales, tal como propusieran en su momento Wilhelm Dilthey (1833-1911) y Robin G. Collingwood (1889-1943) para construir un estatuto jerárquicamente diferenciado para uno de los dos ámbitos o para la historia, o para las ciencias naturales (Popper, 2005, p. 174).

Además, Popper cuestiona la distinción jerarquizada que opera en la academia en torno a la primacía de las ciencias aplicadas respecto a las ciencias sociales y humanistas. Así, los saberes no se distinguen según el ámbito de la realidad al que se refieren ni al tipo de saber requerido por cada uno de esos ámbitos; no es verdad que operaciones del tipo "comprender" se reservan a la historia; y "explicar", a las ciencias naturales. En rigor, todas las ciencias comparten los mismos principios y no tienen sentido las distinciones basadas en lógicas diferentes que nacen de ámbitos de la realidad también diferentes.

Pero el principio de falsación genera también el criterio de demarcación o el lindero que separa la ciencia del sentido común y otros tipos de conocimiento teóricos, aunque todos participen de las mismas dinámicas de solución de problemas. El sentido común considera irrefutable la producción teórica; en tanto que la ciencia considera toda teoría como potencialmente falsable; es decir, toda teoría posee una naturaleza transitoria y provisoria; sobre cada una, sin excepción alguna, pende la amenaza permanente de una posible falsación. En este sentido, lo único que cabe hacer con un nuevo conocimiento es 
falsarlo o refutarlo. No existen marcos teóricos estables ni fijos, sino esquemas abiertos y disponibles a que la realidad misma o los desfases de la aplicación sean los que los deslegitimen. El principio de que una teoría es válida solo si es falsable cuestiona otros criterios de demarcación como, por ejemplo, el propuesto por Thomas Kuhn (19221997) y los historicistas, para quienes la validez depende del carácter significativo de la teoría respecto a las comunidades interpretativas que las originan y les atribuyen sentido y pertinencia.

El dispositivo teórico propuesto por Popper funciona a la manera de esquema tentativo y abierto de resolución de problemas que asegura la producción de teorías generadoras, a su vez, de otros tantos problemas no intencionados que reclaman sucesivamente otras tantas teorías. Así, resulta idealmente imposible sistematizar y axiomatizar las teorías.

\section{Comentarios e implicaciones epistémicas, éticas y políticas}

\section{Aspectos epistémicos}

Popper construye su agenda crítica desde la lógica hipotética deductiva y la reubicación de la teoría en la construcción de los datos, al menos en dos direcciones. La primera apunta contra el positivismo; la segunda, contra toda forma de ideología y sistema cerrado de ideas. Respecto a la primera, cuestiona el principio epistémico heredado de Francis Bacon (1561-1626), uno de los padres del empirismo científico, según el cual conocemos sin marcos teóricos previos — desprovistos de hipótesis o conjeturas - proyectando sobre él la crítica al positivismo del siglo XX cuyo fundamento es conocer con certeza a partir de la experimentación y no de la teoría ${ }^{14}$. A la vez

14 Para una crítica de Popper, según la cual el proceso de falsación no logra trascender el positivismo por remitirse en última instancia a la experiencia, ver 
que reconoce el potencial de Bacon para depurar la ciencia de prejuicios inútiles, ataca y con razón su pretensión de purgar la mente de teorías pues "una mente purgada de esa manera no solo sería una mente pura: sería también una mente vacía” (2005, p. 114).

El segundo punto de su agenda consiste en restaurar aquella porción de la Ilustración desde la cual desmontar la estructura cerrada de las ideologías, las doctrinas y sus correlatos de acción y pensamiento (recordemos que Popper vivió en medio de totalitarismos). Desde esa agenda, en contrapartida, Popper revaloriza la confianza de Francis Bacon en la razón y destaca su influencia en varios aspectos que determinarán el desarrollo futuro de la ciencia (2005, pp. 244 y ss.): la conexión de la ciencia con la utopía del bienestar por medio de la actitud pragmático-tecnológica; la visión acumulativa del conocimiento y, por lo tanto, la concepción del trabajo científico como una empresa cooperativa y organizada; la visión de la naturaleza como libro ilimitadamente abierto y la primacía de la actitud de dominio sobre la naturaleza. Es crítico respecto a cada uno de estos aportes, pero señala que, si bien la inducción no refleja la lógica del entendimiento humano, tuvo el mérito de hacer pensar al ser humano por sí mismo y haber instaurado la autoconfianza y la esperanza en un conocimiento sin límites y libre de las ataduras de los prejuicios religiosos.

La epistemología popperiana influyó decisivamente en el historicismo de Imre Lakatos (1923-1974) y coincide parcial y casualmente (porque ninguno conoció la obra del otro) con la propuesta

Datri et al. (2004, pp. 104 y ss.) y también Hollis, M. (1998, pp. 79 y ss.). Vale aclarar que Popper reconoce explícitamente la construcción teórica del dato y que la falsación no se remite a la experiencia bruta, como si se tratara de un laboratorio, sino a la realidad concebida como campo experimental, de aplicación y de práctica de la teoría. El que la teoría exprese una relación necesaria con la realidad no autoriza a clasificar de positivista a Popper. 
hipotética del filósofo estadounidense Charles Sanders Pierce (18391914). Si bien sus desarrollos son diferentes, ambos conceden un lugar central a la conjetura, valoran la productividad práctica de la teoría (resuelve y abre problemas, a la vez) y reconocen a la comunicación de resultados un rol crucial en la investigación.

Entre los aspectos epistémicos problemáticos de su metateoría, señalamos los siguientes: la exclusión de la práctica científica de toda forma de subjetividad, individual o colectiva; la pretendida unidad metódica de las ciencias en general y de las ciencias sociales en particular y, por último, la idealización de la teoría como la forma ideal y mejor de conocimiento. Revisemos cada uno de estos puntos.

Tal como plantea la teoría de los tres mundos, algunos consideran que Popper constituye el puntal ideológico de una forma de racionalidad liberal que deshistoriza e ignora las agencias y los sujetos de la historia (Datri, 2004, p. 105) y hace del ideal de objetividad procedimental el dispositivo que expulsa del conocimiento toda forma de subjetividad individual o colectiva. Hoy, su pretensión de fundar una objetividad que requiere de una mente totalmente imparcial alejada de las miradas y componentes subjetivos, capaz de neutralizar las emociones, nos resulta indigerible y es quizás el aspecto más polémico para la actual sensibilidad epistémica que, en cambio, revaloriza la subjetividad del investigador, su carga emotiva, sus pertenencias y lazos identitarios, su corporalidad y todas las formas de diversidad posibles, recuperándolas como aspectos pertinentes y significativos del conocer y de la investigación. La aserción respecto a que "la subjetividad (individual o colectiva) es la mejor herramienta de investigación", tan central para la actitud intelectual contemporánea, resultaría, en cambio, inadmisible para Popper.

Otro de los aspectos difíciles de aceptar es su terminante refutación de los esquemas dialécticos de pensamiento, especialmente 
los de Hegel, Marx y Freud, a quienes Popper considera los enemigos más formidables de la sociedad abierta no porque no se los deba cuestionar, sino por el argumento de fondo que sustenta su crítica. Reconocer que "el futuro está abierto de par en par" (1995, p. 203) y que, por tanto, es necesario rechazar cualquier teoría "según la cual hay una trama en la historia" (2005, p. 164) resulta problemático pues convierte a Popper en aliado de las vertientes posmodernas radicales que, al negar la historia, terminan por deslegitimar y desconocer las subjetividades sociales que reclaman formas diversas de pensar y de situarse en la sociedad. ${ }^{15}$

El programa epistemológico de Popper anula las diferencias radicales entre las ciencias (a la unicidad del mundo respecto al conocimiento le corresponde la unicidad de la ciencia), especialmente entre las físicas, naturales y sociales, ya que todas ellas despliegan dispositivos teórico-metodológicos similares basados en el único método deductivo de contrastar. La explicación, la predicción y la experimentación no son enfoques capaces de establecer rupturas estructurales o radicales entre las disciplinas o áreas de conocimiento, sino

15 Sin duda, la obra del epistemólogo argentino Mario Bunge (1919), un filósofo radicado en Canadá y autor de numerosas obras sobre epistemología y metodología científica, muy citada y tomada en cuenta en Latinoamérica, es la prolongación del enfoque popperiano, especialmente en lo que concierne a la negación de la subjetividad y la pretensión de neutralidad de las ciencias. En efecto, Bunge retoma el espíritu de las refutaciones de Popper cuando identifica y descalifica otras aproximaciones como las ciencias sociales inspiradas en el enfoque interpretativo (la interpretación es, al fin y al cabo, un asunto eminentemente subjetivo), el marxismo y el feminismo —entre otras expresiones- por tratarse de ideologías ajenas a los hechos y a los principios de la ciencia objetiva y, sobre todas las cosas, negar uno de sus requisitos fundamentales: el de ejercer la ciencia a partir de actitudes políticamente neutrales. Ver, por ejemplo, una de las últimas producciones de Bunge (1999), en la que plantea su posición respecto a los alcances de las ciencias sociales contemporáneas como la antropología, la sociología y la historia, entre otras. 
tan solo énfasis diversos según el tipo de problemas convocados. En consecuencia, todas las ciencias son iguales porque comparten necesariamente el mismo método. Las ciencias sociales, por otro lado, son comprendidas como parte de los mecanismos adaptativos de la sociedad y, consecuentemente, las teorías resultantes se conciben en términos de reingeniería social.

En efecto, al desplegar en el escenario que le corresponde el método de solución de problemas y acoplarse a los procedimientos de falsación mediante el ensayo y error, su misión es la de rectificar errores o postular por adelantado soluciones posibles y tentativas; o bien, establecer falsaciones en torno a las decisiones que la práctica deslegitima. Sin embargo, las actuales tendencias de las ciencias sociales plantean reparos tanto a la pretendida unicidad metódica de las ciencias, porque reclaman su especificidad también con respecto al enfoque, al método y a los objetivos, como al carácter de reingeniería social y de saber adaptativo en la que se las pretende encasillar porque se las margina del horizonte de sentidos y transformaciones profundas al que aspiran.

Como los cambios y transformaciones teóricas son producto de la lógica autopropulsada de las teorías y del talento creativo del investigador, Popper construye una suerte de epistemología carente de sociología que rechaza y minimiza los factores externos, sociales e históricos que inciden en los cambios teóricos, oscureciendo la relación de las teorías con las comunidades interpretativas y con los contextos que les dan significado. Además, desconoce, en el fondo, el potencial cognitivo de la relación del conocimiento teórico con otras formas de saberes con lo cual refuerza el teoricismo y promueve la idealización de la figura del teórico-investigador, protagonista único de la clave de comprensión de los problemas y de la transformación progresiva de la realidad. 


\section{2}

\section{La dinámica teórica autorregulada.}

\section{Ciencia, poder, naturaleza y mercado}

La perspectiva ética y política de Popper tiene mucho que ver con su visión del carácter progresivo de la ciencia y la técnica, basado en el esquema de adición acumulativa de mejoras que trasunta la confianza en su ilimitada capacidad para resolver problemas; en el fondo, se trata de una lectura epistemológica de la ideología del progreso. En esta visión, el futuro popperiano se inscribe en la prognosis de gloria constituida por los logros potenciales que la ciencia es capaz de construir; el futuro es el resultado de la acumulación sucesiva de éxitos presentes producidos por el movimiento perpetuo de los mecanismos del pensamiento científico autopropulsado que procede de avance en avance, indefinida e ininterrumpidamente. El futuro es abierto e incierto, pero por ningún motivo inquietante. $\mathrm{Y}$ ello pese a su plena conciencia del clima cultural adverso y cuestionamientos a la ciencia provocados por hechos como, por ejemplo, la bomba de Hiroshima. La siguiente cita es sumamente elocuente al respecto si tomamos en cuenta que fue pronunciada en 1989, en una conferencia en el ocaso de su vida y en un punto muy alto de la relativización y crítica radical a la ciencia y la técnica por sus amenazantes consecuencias:

Pero tan pronto como se había creado el estado de bienestar y todo marchaba bien en Occidente, comenzaron los grandes gritos e improperios de los intelectuales acerca de nuestra mala época, de nuestra sociedad, de nuestra civilización, de nuestro medio ambiente. Comenzaron las tremendas exageraciones sobre las destrucciones y las contaminaciones, que presuntamente habíamos causado por nuestra codicia, para aniquilar lo más pronto posible las ruinas de un mundo que una vez fue tan hermoso. Es cierto que toda vida está siempre amenazada. Todos nosotros, supongo, vamos ciertamente a morir; tarde o temprano. Peligro ha habido siempre, siempre, desde el origen de la vida, también para el medio ambien- 
te. Gracias a la ciencia natural y a la tecnología y a la industria, por primera vez desde la creación de nuestro sistema solar estamos en situación de hacer algo por el medio ambiente, y todos los científicos naturales y técnicos se esfuerzan por ello. Sin embargo, se les culpa de destruir la naturaleza. Entretanto, hace ya tiempo que fueron puestos a salvo, con toda tranquilidad, el hermosísimo lago Zürcher y también el enorme lago Michigan... (1995, p. 212)

El dispositivo de adición sucesiva de pequeñas pero continuas mejoras que provee la ciencia alimenta el horizonte de temporalidad corta que se desentiende del futuro y a partir del cual las consecuencias remotas o imprevistas del desarrollo tecnológico resultan inimputables precisamente porque el desempeño científico está necesariamente atravesado por limitaciones inherentes que obstaculizan la capacidad de control, en gran medida, debido a la inconmensurabilidad de los procesos naturales y al carácter impredecible e involuntario de los descubrimientos científicos y tecnológicos que generan un marco de inevitable y necesaria incertidumbre (1995, p. 221).

La traducción del futuro abierto en el contexto de la ciencia y la técnica y su relación con la naturaleza resulta en la noción de azar que significa la imposibilidad de anticipar y someter a control social —ex ante - las consecuencias de ese conocimiento y de las intervenciones tecnológicas. Así, Popper coloca el sustrato epistémico que niega a la ciencia y la tecnología un ámbito social y político de control y previsión de tal modo que los desastres naturales y sociales solo recibirán el trato de consecuencias indeseables e involuntarias, de daños colaterales o "no buscadas consecuencias del desarrollo del conocimiento científico y la tecnología” (2005, p. 240), conocimientos autopropulsados desde su propia lógica que no deben estar sujetos, por principio, a controles externos.

Así, la imprevisibilidad de las consecuencias de los conocimientos o aplicaciones tecnológicas es una debilidad constitutiva e inheren- 
te al saber científico, y es un lugar desde el cual cuestiona la pretensión baconiana de que el saber es poder, por la única razón de que la dinamia de la ciencia va del no saber (un problema irresuelto) al no saber (otro problema irresuelto). La imprevisibilidad azarosa es parte de la impotencia del saber y la incapacidad para anticipar sus propias consecuencias y dominar el futuro es una consecuencia lógica de tal manera de concebir el conocimiento (2005, p. 113). De esa manera, sustrae la ciencia de cualquier mecanismo político de control social.

Vemos que Popper construye el sustrato epistémico de aquella actitud generalizada que posterga indefinidamente las evaluaciones anticipadas de los posibles impactos y consecuencias de la ciencia y la tecnología por no contar con un marco seguro de conocimiento. Vemos también que destruye toda posibilidad de imaginación anticipada y control de las consecuencias, como el principio de precaución, pues se requiere alejar la ciencia de las injerencias inoportunas de la política (como ha sucedido en los totalitarismos). Al sustentar la epistemología en una visión del mundo y de la historia como realidades abiertas e imprevisibles, la ciencia no posee la capacidad de anticipar y proyectar el futuro: debe jugar en un marco de impredecibilidad constitutiva y necesaria, de lo contrario, estará sujeta a los determinismos de los marcos comunes. No obstante, la ciencia no se desentiende del poder, lo reasume de otra manera en el sentido de que la ciencia no debe estar sujeta a controles; pero es poder en el sentido de que se trata de un saber de dominio sobre la naturaleza no exento de riesgos, aunque Popper nunca aportó a profundizar las consecuencias de este dominio no deseado de la ciencia sobre la naturaleza, pero de todas maneras inscrito en su dinámica porque se trata de daños potenciales inintencionales, como se verá más adelante. Comentando sobre Bacon en torno a esta idea, afirma lo siguiente:

Tuvo la visión de una nueva época, de una era industrial que también sería la era de la ciencia. En referencia al descubrimiento 
accidental de la pólvora y de la seda, habló de la posibilidad de una investigación científica sistemática en vista a otras substancias y materiales, y de una nueva sociedad en la cual los hombres, a través de la ciencia, encontraran la salvación de la miseria y de la pobreza. De esta suerte, la nueva religión de la ciencia sostuvo una nueva promesa del cielo en la tierra, de un mundo mejor que, con ayuda del nuevo conocimiento, los hombres crearían por sí mismos. Saber es poder — dijo Bacon—, y esta idea, esta peligrosa idea del dominio del hombre sobre la naturaleza, de los hombres como dioses, ha sido una de las ideas más influyentes a través de las cuales la religión de la ciencia ha transformado nuestro mundo. (2005, p. 113)

Al mismo tiempo, articula el poder político con la ciencia según el principio de que "al científico solo le interesa la verdad, no el poder. El político es quien se ocupa del poder", y establece una clara jerarquía a favor de la ciencia (de la verdad): "el conocimiento es mucho mejor que el poder” (2005, p. 240). Retoma así el lugar kantiano para fundar la ética: la racionalidad y sus fines. Pero la responsabilidad tecnológica es un asunto librado a la racionalidad del científico y a su rol de tutela; los poderes derivados del conocimiento deben ser controlados desde el conocimiento mismo y por las lógicas que le son inherentes.

Es la tutela del científico, en especial la del científico social, quien debe prevenir y anticipar el descontrol de la tecnología. Ahora bien, según Popper, el científico social está atravesado por la tensión de un doble rol: su rol prioritario consiste en identificar amenazas contra la libertad humana y luchar contra ellas, proveyendo de "contramedidas efectivas" (2005, p. 160) desde el horizonte de una ciencia independiente que asegure un futuro indeterminado "abierto de par en par" (p. 103). El segundo rol del científico social, subordinado al primero, consiste en alertar contra los peligros de la ciencia y la tecnología solo en tanto comparables a los peligros inherentes al 


\section{6}

totalitarismo y no como un atentado contra la misma naturaleza o a causa de una mínima duda acerca de la autosostenibilidad del mundo natural. Así, Popper encarna el principio de la ética según el cual lo social y lo natural no solo son órdenes separados sino también jerárquicamente ubicados (lo social tiene prioridad sobre la naturaleza); además, no constituyen escenarios intrínsecamente ligados y en los que se juega el futuro de la raza humana. En Popper calza muy bien la tensión antropocéntrica de la ética tradicional que invisibiliza la naturaleza, minimiza las consecuencias de la ciencia para la especie y confina la responsabilidad del científico al ámbito social e intersubjetivo como se recoge en la siguiente extensa cita:

Se podría cuestionar que corresponda verdaderamente al científico una responsabilidad distinta de la que corresponde a cualquier otro ciudadano o a cualquier otro ser humano. Pienso que la respuesta es que todo el mundo tiene una responsabilidad especial en el campo en que tiene un poder o un conocimiento especial. Así, en lo fundamental, solo los científicos pueden evaluar las implicaciones de sus descubrimientos. El profano y, por tanto, el político, no sabe lo suficiente. Esto vale tanto para los nuevos productos químicos para aumentar el rendimiento de la producción agrícola como para las nuevas armas. De la misma manera que, en otra época [...] es el acceso potencial al conocimiento lo que crea la obligación. Solo los científicos pueden prever los peligros, por ejemplo, del aumento de la población, o de los aumentos en el consumo de productos derivados de petróleo, o los peligros inherentes a los desechos atómicos, incluso en tiempos de paz. Pero ¿saben ellos lo suficiente sobre todo esto? ¿Son conscientes de sus responsabilidades? Algunos lo son, pero me parece que muchos no lo son. Algunos quizás, están demasiado ocupados. Otros, tal vez, son demasiado irreflexivos. De una u otra manera, las repercusiones no intencionales de nuestro incauto progreso tecnológico no parecen ser responsabilidad de nadie. Las posibilidades de aplicación parecen intoxicantes. Aunque mucha gente se haya preguntado hasta qué punto el progreso tecnológico 
nos hace más felices, pocos han sentido como su responsabilidad el descubrir cuánto sufrimiento evitable es consecuencia inevitable, aunque no intencional, del progreso tecnológico.

El problema de las consecuencias no intencionales de nuestras acciones, consecuencias que no solo no son intencionales, sino que a menudo son muy difíciles de prever, es el problema fundamental del científico social.

Puesto que el científico natural se ha implicado inextricablemente en la aplicación de la ciencia, también él debería considerar como una de sus responsabilidades especiales el prever, en la medida de lo posible, las consecuencias no intencionales de su trabajo y llamar la atención, desde el primer momento, sobre todo aquellos que deberíamos esforzarnos por evitar. (2005, pp. 161-162)

Respecto a la política, en cierto punto, Popper (1995, pp. 220 y ss.) relaciona explícitamente los principios del mercado con los posibles marcos de control social y político de la ciencia y la tecnología. Propone sustituir la ideología del mercado libre por el principio de limitar la libertad solo allí donde sea necesario por motivos únicamente urgentes, sin la seguridad de encontrar los límites de lo necesario debido a la indeterminación y complejidad propia de los problemas ambientales. Por ello, no se puede postular sin más que las regulaciones ambientales atentan contra la libertad pues toda sociedad libre, garantizada desde el Estado, presupone regulaciones, limitaciones y restricciones que benefician la libertad general del ciudadano. Tampoco es posible responder con demasiada anticipación a tales problemas. Establecer tales restricciones será siempre problemático y "una cuestión de la experiencia”, es decir, un procedimiento ex post, no anticipable:

... evidentemente, la legislación tiene que prohibir la emisión de gases venenosos en el proceso de producción, y evidentemente, la 


\section{8}

frontera entre gases venenosos y formas más benignas de contaminación, como los que producen los automóviles, es indeterminada o problemática: depende entre otras cosas de la densidad del tráfico. (1995, p. 221)

En lo tocante a la idoneidad de los tribunales científicos y expertos como instancias naturales de control, constatamos que Popper no toma nota de las transformaciones producidas por la forma dominante de producción de conocimientos, la cual ya no gira en torno a una comunidad científica como sujeto ideal y abstracto que procesa las discusiones y asume la responsabilidad de control y evaluación de la ciencia, sino a fuerzas corporativas y "contextos institucionales de alta tecnología directamente relacionados con aplicaciones tecnológicas tanto comerciales como militares" (Lander, 1994, p. 75).

\section{Teoría y praxis. El pensamiento crítico de la escuela de Frankfurt}

La escuela que más ha aportado para develar la relación de diversas formas de teoría con la comprensión del presente en relación con la emancipación social y a la humanización de la existencia - la praxis - es la escuela de Frankfurt, que ha condicionado en gran medida el pensamiento y el tono de la teoría social latinoamericana. Estuvo constituida por el conjunto de investigadores alemanes que compartieron el enfoque crítico y progresista del pensamiento social cuyos nombres más conocidos son Theodor Adorno (19031969), Max Horkheimer (1895-1973), Herbert Marcuse (18981979), Erich Fromm (1900-1980) y Walter Benjamin (1892-1940), todos ellos integrantes del Instituto de Investigación Social fundado en Frankfurt en 1924, con el objetivo de investigar y comprender el marxismo. En 1933 el instituto fue prohibido por el nazismo y Max Horkheimer, entonces director, junto con otros miembros —algu- 
nos de ellos judíos - debieron exiliarse y se radicaron en la Universidad de Columbia (Nueva York), donde permanecieron hasta 1943.

Allí, en contacto con una sociedad capitalista avanzada y altamente industrializada, centraron su reflexión en las consecuencias deshumanizantes de la racionalidad y el progreso técnico. La teoría crítica, herencia del marxismo, constituye una arremetida contra los totalitarismos políticos, el positivismo y el industrialismo, a los que consideran "filosofías y ciencias que sacrifican lo individual y particular a la Totalidad de un sistema mitificado (Hegel), al Ser (Heidegger), a la ciencia objetiva (los positivistas como Karl Popper y Hans Albert), o bien al proceso histórico (Marx y Engels). Estas teorías bastante heterogéneas tienen en común subordinar el sujeto al objeto, lo particular a lo general" (Zima, 1973, p. 24).

Los diversos miembros de esta escuela, basados en la relectura de filósofos como Hegel, Marx, Freud y Nietzsche, desarrollan una concepción de teoría (una teoría crítica) cuya función esencial es develar los diversos mecanismos de enajenación del presente y proponer prácticas emancipatorias y humanizantes. Dicho enfoque, que privilegia la actitud política del sujeto investigador, pretende desenmascarar la pretensión de neutralidad objetiva del positivismo, neutralidad a la que acusan de ingenua y servicial respecto al orden existente, así como superar el horizonte meramente instrumental del conocimiento y, por lo tanto, de la teoría.

Hemos escogido dos autores paradigmáticos de esta orientación: Max Horkheimer, miembro de la primera hora de la escuela y uno de sus principales orientadores, y Jürgen Habermas (1929), el último en incorporarse a ella en 1956, en medio de las críticas radicales a la orientación excesivamente especulativa que culminarían con su cierre. Ambos sociólogos y filósofos alemanes compartieron su preo- 
cupación por la teoría y su significado político y social, y desarrollaron sobre bases comunes los conceptos de "teoría crítica” y "teoría dialéctica”, respectivamente, los cuales serán analizados a continuación.

\section{La teoría crítica de Max Horkheimer}

El pensamiento de Horkheimer, no obstante su clara filiación marxista, combina otros aportes como los de Nietzsche y Freud en un contexto histórico caracterizado por el ascenso del nazismo en Alemania y del estalinismo en la Unión Soviética, los cuales no solo frustraron la inminente transformación revolucionaria, sino que pusieron de manifiesto su tendencia a la totalización a la que es necesario enfrentar con la reflexión filosófica y sociológica. Por lo tanto, el aporte de Horkheimer no solo cuestiona al capitalismo sino también - y con crudeza - la concreción estalinista del marxismo, a la vez que construye una de las críticas más profundas de la razón abstracta y del fetichismo del dato que caracteriza al cientifismo positivista.

Para comprender los mecanismos de la dominación Horkheimer consideró necesario profundizar fenómenos como la ideología y la falsa conciencia que se interiorizan en la estructura psíquica de los individuos, así como en el ejercicio de la ciencia como factores determinantes del éxito o fracaso de los procesos emancipatorios. $\mathrm{Su}$ propuesta se desarrolla en uno de los ensayos más conocidos y que más profunda huella ha dejado en las ciencias sociales latinoamericanas, a pesar de ser publicado en 1937, Teoría tradicional y teoría crítica ([1937] 2003), considerado el acta fundacional del pensamiento crítico. Su telón de fondo es el cuestionamiento al positivismo y las prácticas científicas de subordinación que generan hostilidad indiscriminada y sospecha ante cualquier esfuerzo crítico. Así, la ciencia es un territorio donde se juega la emancipación, ya que lo que afecta a la teoría afecta también a la praxis liberadora y, si la teoría no se 
continúa, “... no queda lugar para la esperanza de mejorar fundamentalmente la existencia humana” (2003, p. 263).

Horkheimer resume y da forma a la doctrina oficial de la escuela sobre la teoría, conjuntamente con el aporte de Theodor Adorno. Su punto de partida es la filosofía marxista y la tesis central consiste en que "la acción conjunta de los hombres en la sociedad es la forma de existencia de su razón” (2003, p. 237), es decir, los hombres piensan tal como actúan en sociedad, colectivamente. Por lo tanto, la ciencia no es un mecanismo lógico autosuficiente y su pertinencia y productividad no dependen únicamente de sus elementos formales e internos (como pretendería Popper); antes bien, la transformación de las estructuras científicas (las teorías, los métodos, los temas) deriva de factores sociales en un sentido muy estricto: el modo de producción teórica responde al modo de producción histórico, de tal manera que las preferencias teórico-metodológicas derivan de y convergen en la praxis social (pp. 228-231).

Una forma de teoría, a la que denomina "tradicional", acepta la realidad y la acción como algo dado o suma de facticidades y fuerzas naturales inmutables que deben ser aceptadas; tal actitud teórica es incapaz de percatarse de que el mundo percibido y fáctico es producto de la praxis y que, por tanto, el conocimiento y la percepción derivan de ella; le pasa por alto que la realidad "no está ahî" y que "lo fáctico está mediado por la praxis social como totalidad" (p. 236). El concepto de teoría tradicional se asume y se entroniza como forma independizada, "como si se lo pudiera fundamentar a partir de la ciencia íntima del conocimiento... o de alguna otra manera ahistórica, se transforma en una categoría cosificada, ideológica” (pp. 228-229).

Es necesario superar la teoría tradicional por medio de la conciencia de su relación con los procesos sociales y con la convicción de 


\section{2}

que se trata de un producto determinado por el trabajo del científico. Este punto de vista separa al autor de otras corrientes que, si bien imbrican las teorías con el aparato social, las conciben como realidades autosuficientes determinadas "cabe si"; al negar que tales teorías son producto de la división social del trabajo, son incapaces tanto de determinar su función respecto a la autoconservación del orden establecido como de tomar conciencia del ocultamiento que propician con respecto a las relaciones y determinaciones de las realidades sociales.

Surge así la necesidad de un nuevo concepto teórico para superar la falsa conciencia que envuelve la teoría tradicional: la teoría crítica, concebida como un comportamiento crítico y emancipatorio, una forma de pensar que es, al mismo tiempo, una forma de actuar sobre la sociedad que trasciende finalidades como la solución de problemas o un mejor funcionamiento de la estructura para proyectarse hacia la emancipación. El rasgo distintivo de la teoría crítica no radica en el objeto (qué se comprende) sino en el sujeto de conocimiento. Él no es el lugar en el que confluyen el conocimiento y su objeto; el sujeto de conocimiento, más bien, es el individuo cruzado por relaciones reales con otros individuos y grupos, con una clase y con la naturaleza (p. 243), inmerso en un proceso histórico concreto. Por último, la única instancia de juicio de la teoría crítica, o su criterio de demarcación respecto a la teoría tradicional, es su interés por la supresión de la injusticia social.

Todas las teorías responden a uno u otro esquema y estos agotan todas las posibilidades de ejercicio teórico, tanto los propios de la matemática, la física como de las ciencias sociales. Si bien ambas formas de producción teóricas son antagónicas, es posible establecer interacciones ya que la teoría crítica integra, requiere y recupera aspectos de la teoría tradicional, pues no se trata de desechar la ciencia tradicional como totalidad, sino de integrarla en la perspectiva de la transformación social emancipatoria. La Tabla 2, un tanto extensa y detallada, sistematiza los 
rasgos contrastados de ambas formas de producción teórica, así como la base paradigmática y supuestos metateóricos que las constituyen.

\author{
Tabla 2
}

Teoría tradicional y teoría crítica según Horkheimer

\begin{tabular}{|c|c|}
\hline \multicolumn{2}{|c|}{ Formas de producción teórica según Horkheimer (1937) } \\
\hline Teoría tradicional & Teoría crítica \\
\hline \multicolumn{2}{|c|}{ Concepciones sobre la realidad (sociedad, naturaleza y hombre) } \\
\hline $\begin{array}{l}\text { La realidad es previa y sin contradic- } \\
\text { ciones, susceptible de ser comprendida } \\
\text { conceptualmente. }\end{array}$ & $\begin{array}{l}\text { - La realidad es un todo determinado por rela- } \\
\text { ciones y contradicciones sociales. }\end{array}$ \\
\hline $\begin{array}{l}\text { - La naturaleza es exterior en cuanto reali- } \\
\text { dad suprahistórica. }\end{array}$ & $\begin{array}{l}\text { - La naturaleza es exterior en cuanto suma de } \\
\text { factores aún no dominados por la actividad hu- } \\
\text { mana (no es suprahistórica). }\end{array}$ \\
\hline $\begin{array}{l}\text { La realidad social es escindida y com- } \\
\text { partimentada: segmenta la realidad en } \\
\text { ciencias especializadas, separa teoría y } \\
\text { praxis, pensamiento y acción, individuo } \\
\text { y sociedad. }\end{array}$ & $\begin{array}{l}\text { La compartimentación de la realidad social } \\
\text { cobra el carácter de contradicción conscien- } \\
\text { te. Relativiza la separación entre individuo y } \\
\text { sociedad. Las distinciones y separaciones son } \\
\text { funciones surgidas del obrar humano con } \\
\text { arreglos afines y son reflejo de las relaciones } \\
\text { sociales y de producción. La realidad y el cono- } \\
\text { cimiento son producidos por la praxis social. }\end{array}$ \\
\hline $\begin{array}{l}\text { La sociedad (la cultura, la economía) es } \\
\text { exterior al sujeto; se trata de procesos } \\
\text { extrahumanos y naturales que se expli- } \\
\text { can a partir de mecanismos y funciones } \\
\text { mecánicas. }\end{array}$ & $\begin{array}{l}\text { - La sociedad (la cultura y la economía) es un } \\
\text { producto del obrar humano y son formas } \\
\text { históricas. Constata el carácter inhumano de } \\
\text { la sociedad actual y pone el pensamiento al } \\
\text { servicio de su transformación. }\end{array}$ \\
\hline $\begin{array}{l}\text { Los individuos y los grupos se comprenden } \\
\text { de manera aislada a partir de conceptos } \\
\text { puros y simples. Las relaciones se limitan a } \\
\text { combinar las situaciones espirituales (ideas) } \\
\text { con las situaciones sociales (contextos). }\end{array}$ & $\begin{array}{l}\text { - Parte de una concepción del hombre que se } \\
\text { opone a sí mismo hasta no producir la identi- } \\
\text { dad. Los conceptos develan determinaciones } \\
\text { y contradicciones. }\end{array}$ \\
\hline $\begin{array}{l}\text { Construye un ego que se asume autónomo, } \\
\text { abstracto y origen del mundo. Construye } \\
\text { un nosotros retórico (la raza, la nación). }\end{array}$ & - Se opone al ego aislado y al nosotros retórico. \\
\hline
\end{tabular}




\begin{tabular}{|c|c|}
\hline \multicolumn{2}{|c|}{ Formas de producción teórica según Horkheimer (1937) } \\
\hline Teoría tradicional & Teoría crítica \\
\hline $\begin{array}{l}\text { - Se enfoca en el objeto de conocimiento. } \\
\text { En el sujeto pensante confluyen conoci- } \\
\text { miento y objeto. }\end{array}$ & $\begin{array}{l}\text { - Se construye a partir del sujeto de conoci- } \\
\text { miento: consciente de las relaciones con otros } \\
\text { individuos y grupos, clases y con la naturaleza. }\end{array}$ \\
\hline \multicolumn{2}{|c|}{ Estructura y elementos de las teorías } \\
\hline $\begin{array}{l}\text { - Supone la invariabilidad esencial de la re- } \\
\text { lación entre sujeto, teoría y objeto. }\end{array}$ & $\begin{array}{l}\text { - Supone una lógica dialéctica: el conocimiento } \\
\text { transforma la estructura social en su totalidad, } \\
\text { transforma el sujeto y el rol del pensamiento. }\end{array}$ \\
\hline $\begin{array}{l}\text { Valida el presente. Al servicio de una to- } \\
\text { talidad que se renueva a sí misma: con- } \\
\text { formismo y quietismo. }\end{array}$ & $\begin{array}{l}\text { - Expresa el secreto del presente y traza una lí- } \\
\text { nea de lucha contra lo establecido. }\end{array}$ \\
\hline $\begin{array}{l}\text { - Se organiza según lógica formal y en fun- } \\
\text { ción del dominio de la naturaleza. }\end{array}$ & $\begin{array}{l}\text { - Teoría como momento de una praxis orientada } \\
\text { hacia formas sociales nuevas. El criterio de eva- } \\
\text { luación es su capacidad de transformación social. }\end{array}$ \\
\hline $\begin{array}{l}\text { - Necesidad lógica según paradigma de } \\
\text { ciencias biológicas. }\end{array}$ & $\begin{array}{l}\text { - Necesidad concreta, propia del acontecer } \\
\text { práctico. La necesidad descansa en los acon- } \\
\text { tecimientos que se pueden determinar e in- } \\
\text { fluir racionalmente. }\end{array}$ \\
\hline $\begin{array}{l}\text { - Los conceptos de causa, condición o fun- } \\
\text { ción son los productos clave. }\end{array}$ & $\begin{array}{l}\text { - Las fuerzas, contrafuerzas y contradicciones } \\
\text { son los conceptos clave. }\end{array}$ \\
\hline $\begin{array}{l}\text { - Jerarquización; los hechos son casos ais- } \\
\text { lados, ejemplares o materializaciones de } \\
\text { los géneros por deducción. Atemporali- } \\
\text { dad que esconde las diferencias tempora- } \\
\text { les entre los sistemas. }\end{array}$ & $\begin{array}{l}\text { - El cambio domina la realidad social, se supe- } \\
\text { ra la deducción al identificar los antagonis- } \\
\text { mos sociales y su agudización. }\end{array}$ \\
\hline $\begin{array}{l}\text { Hipotética: resuelve problemas. Productiva } \\
\text { en dos sentidos: crea valores (aplicaciones) } \\
\text { y posibilita la reproducción de un sistema. }\end{array}$ & $\begin{array}{l}\text { - Comportamiento crítico: no busca subsanar } \\
\text { inconvenientes ni optimizar el funciona- } \\
\text { miento de la estructura. }\end{array}$ \\
\hline $\begin{array}{l}\text { - Se funda en juicios categóricos: afirmacio- } \\
\text { nes sobre la realidad que la describen y } \\
\text { explican, pero no la transforman. }\end{array}$ & $\begin{array}{l}\text { - Se funda en juicios de existencia: concede im- } \\
\text { portancia relativa a los juicios de existencia y } \\
\text { se centra en el juicio que denuncia procesos } \\
\text { de alienación que deben ser superados. }\end{array}$ \\
\hline $\begin{array}{l}\text { - Tiende a conformar marcos generalmen- } \\
\text { te aceptados. }\end{array}$ & $\begin{array}{l}\text { - Se refiere a la totalidad, pero no es general- } \\
\text { mente reconocida. Es minoritaria e incómoda. }\end{array}$ \\
\hline
\end{tabular}




\section{5}

\begin{tabular}{|c|c|}
\hline \multicolumn{2}{|c|}{ Formas de producción teórica según Horkheimer (1937) } \\
\hline Teoría tradicional & Teoría crítica \\
\hline $\begin{array}{l}\text { - Considera la teoría crítica como parcial, } \\
\text { injusta e improductiva. }\end{array}$ & $\begin{array}{l}\text { - Sospecha de categorías como mejor, útil, ade- } \\
\text { cuado, productivo, valioso... }\end{array}$ \\
\hline $\begin{array}{l}\text { - La praxis es exterior al sistema. Separación } \\
\text { entre valor e investigación, conocimiento } \\
\text { y acción, teoría y praxis pues preserva al } \\
\text { investigador de las contradicciones y le } \\
\text { otorga un marco fijo a su actividad. }\end{array}$ & $\begin{array}{l}\text { - La praxis constituye el sistema. El científico } \\
\text { ejerce su praxis en el ejercicio teórico crítico. }\end{array}$ \\
\hline $\begin{array}{l}\text { - Pensar cabe sí mismo. La razón es la fuente } \\
\text { de la crítica de sí misma, sin ser ni emanci- } \\
\text { patoria ni pragmática. Es estéril. Ordena y } \\
\text { extrae de sí los fines de tal ordenamiento. }\end{array}$ & $\begin{array}{l}\text { - Pensar referenciado por relaciones y activi- } \\
\text { dad humana. Conocimiento del hacer en la } \\
\text { historia y comprensión de las contradiccio- } \\
\text { nes contenidas en la propia existencia. }\end{array}$ \\
\hline \multicolumn{2}{|c|}{ Relación con la temporalidad } \\
\hline $\begin{array}{l}\text { - Valora el presente: funda utopías abs- } \\
\text { tractas que parten de la idealización del } \\
\text { estado actual de las fuerzas productivas. }\end{array}$ & $\begin{array}{l}\text { El presente debe ser superado dialécticamente. } \\
\text { La realización futura define los aspectos recu- } \\
\text { perables de la teoría. El futuro constituye un } \\
\text { pensamiento a modo de fantasía: la imagen del } \\
\text { futuro que surge de la comprensión del presen- } \\
\text { te determina los pensamientos y las acciones. }\end{array}$ \\
\hline $\begin{array}{l}\text { El investigador es un diagnosticador so- } \\
\text { ciológico sin conciencia de los intereses } \\
\text { políticos: previene con verosimilitud he- } \\
\text { chos de diversa naturaleza sin conexión } \\
\text { necesaria con los anhelos. }\end{array}$ & $\begin{array}{l}\text { El investigador se concentra en un anhelo } \\
\text { no realizado. Prefigura acontecimientos que } \\
\text { pueden lograr la emancipación. }\end{array}$ \\
\hline $\begin{array}{l}\text { - Los juicios categóricos cambian según su } \\
\text { contenido intrínseco. }\end{array}$ & $\begin{array}{l}\text { - Los juicios de existencia se transforman en la } \\
\text { medida que cambian las relaciones sociales. } \\
\text { Una teoría permanece a pesar de los cambios } \\
\text { si las relaciones de producción que la hacen } \\
\text { posible no se han transformado. }\end{array}$ \\
\hline $\begin{array}{l}\text { - Conforma un corpus tradicional acu- } \\
\text { mulativo, traspasable de una generación } \\
\text { a otra. }\end{array}$ & $\begin{array}{l}\text { - No tiene carácter aditivo: los nuevos con- } \\
\text { tenidos no se añaden a otros ya dados pues } \\
\text { constituyen un todo unitario con la sociedad. }\end{array}$ \\
\hline $\begin{array}{l}\text { - Se reproduce y transmite merced a la le- } \\
\text { galidad orgánica o sociológica. }\end{array}$ & $\begin{array}{l}\text { - El enfoque crítico vive de la voluntad de } \\
\text { transformación. }\end{array}$ \\
\hline
\end{tabular}

Elaboración de los autores a partir del estudio Teoría tradicional y teoría crítica de Horkheimer (2003, pp. 223-271). 


\section{6}

El aporte de Horkheimer es sumamente fecundo para comprender el carácter ambivalente de la ideología y la cultura —y de las teorías - como mecanismos poderosos que interiorizan psicológicamente la necesidad de reproducir el sistema. El poder de la teoría tradicional para perpetuar el orden establecido va de la mano con su impotencia y se expresa en los consecutivos fracasos para transformar la realidad, intentos que culminan siempre en formalismos vacíos o reformas epidérmicas e inútiles. Por lo tanto, adolecen de fisuras a partir de las cuales es posible posicionar el enfoque crítico.

\section{La escuela de Frankfurt de segunda generación. Jürgen Habermas: teoría crítica e intereses del conocimiento}

Jürgen Habermas (1929) es miembro de segunda generación de la escuela, junto con otros discípulos suyos como Claus Offe (1940), Oskar Negt (1934), Albrecht Wellmer (1933-2018) ${ }^{16}$ y Alfred Schmidt (1940), este último discípulo de Horkheimer. Uno de sus méritos ha consistido en prolongar el programa de sus antecesores al relacionar la epistemología con otras dimensiones de la vida social: la política, los movimientos sociales, la comunicación y la cultura (Muñoz, 2005, pp. 250 y ss.).

Jürgen Habermas desarrolla y profundiza la crítica heredada de Horkheimer y Theodor Adorno (1903-1969) sobre la razón instrumental, y determina, de inicio, que la primacía de la racionalidad instrumental (la que ajusta la relación entre medios y fines) sobre la racionalidad objetiva (la que determina los fines) es el rasgo distintivo del pensamiento contemporáneo. Si bien en este sentido se adhiere a la crítica antipositivista de Popper, en el marco de un programa que busca culminar una modernidad inacabada, se distancia

16 Albrecht Wellmer se graduó de doctor en Filosofía (1966) con la tesis Metodología como teoría del conocimiento. La ciencia en Karl Popper. 
de él por la inspiración dialéctica y hermenéutica de su pensamiento ya que, al retomar la praxis como determinante fundamental del conocimiento, supera el encierro de la reflexión epistemológica en los estrechos linderos de las condiciones y procesos de los procedimientos lógicos que caracteriza la propuesta de Popper.

Por lo tanto, y por las polémicas entre ambos, Habermas puede ser considerado como la antítesis de Popper. Según Habermas, el territorio epistémico desde donde se encumbra la racionalidad instrumental es el positivismo al cual se propone desmontar sobre la base de una concepción amplia del conocimiento como saber y de la inclusión del interés como uno de sus elementos constitutivos; solo así es posible deslegitimar la pretensión de objetividad de la ciencia e integrar, desde este nuevo enfoque, la teoría y la praxis.

\section{Los intereses del conocimiento}

El primer aspecto básico de su teoría es concebir el conocimiento como el conjunto de saberes que hacen posible la acción humana. Desde allí, redimensiona, mediante reducción, el lugar de la ciencia y, por ampliación, el alcance de la epistemología: la ciencia no agota el conocimiento ya que solo es una de sus modalidades posibles; por tanto, la epistemología no se puede reducir al conocimiento científico y debe considerar otras formas de producción teórica; tampoco es posible que el problema del conocimiento se deba reducir al método, tal como pretende el positivismo, pues ello desplaza al sujeto que conoce del proceso de conocimiento y opaca el hecho de que el sujeto que conoce forma parte también del objeto de conocimiento. Al incluir la ciencia en el telón de fondo de otras formas de saber, al expandir la epistemología hacia otros saberes y liberar el conocimiento de su encierro en el método, pone las bases de una crítica de la teoría instrumental cuya intención final es relacio- 
nar el conocimiento con el proceso de autoconstitución del hombre y de la sociedad. A diferencia de Popper que ancla su teoría del conocimiento en la metafísica o la cosmología, Habermas considera que tanto la teoría de la sociedad como la del conocimiento se necesitan mutuamente al punto de que toda teoría del conocimiento es al mismo tiempo una teoría de la sociedad (Laso, 2004, p. 15).

El segundo aspecto de su teoría retoma la mutua implicación entre conocimiento y sociedad, y relaciona el conocimiento con las formas de desarrollo histórico de la sociedad. El producto de tal relación es el concepto clave de intereses del conocimiento 17. Habermas describe a la sociedad como constituida por dos dimensiones en torno a las cuales la humanidad se transforma a sí misma a lo largo de la historia: la dimensión técnica, construida sobre las relaciones con la naturaleza centradas en el trabajo productivo y reproductivo, y la dimensión social, construida a partir de las relaciones entre los hombres centradas en la cultura y las normas sociales.

Es evidente que en la sociedad contemporánea la dimensión técnica domina sobre la social y el establecimiento de una relación más equilibrada entre ellas es posible al elucidar los intereses de conocimiento que las atraviesan, entendidos como las orientaciones básicas de la sociedad humana respecto al proceso de reproducción y autoconstitución del género humano. El interés técnico es la orientación básica de la dimensión técnica y de su respectiva forma de conocimiento, encaminada al dominio de la naturaleza mediante las ciencias naturales. El interés práctico es la orientación básica de la dimensión social y de su respectiva forma de conocimiento orientada al desarrollo de las relaciones entre los hombres y su entendimiento mutuo mediante las ciencias hermenéuticas.

17 Este concepto se describe en el estudio de Habermas (1986b, pp. 164 y ss.). También cfr. Ureña, E. M. (1998, pp. 95 y ss.). En este aspecto sigo la sistematización de Laso, S. I. (2004, pp. 13 y ss.). 
La crítica al positivismo es obvia. En primer lugar, porque ninguna investigación - y su respectiva construcción del objeto de conocimiento - es neutral y desinteresada respecto a los intereses; más bien el interés es un elemento constitutivo del conocimiento y se produce según las orientaciones de autoconstitución del género humano. Por lo tanto, no se trata de captar un objeto para comprenderlo tal cual es, como tampoco es posible considerar el conocimiento una copia de la realidad. En segundo lugar, los intereses no solo condicionan la investigación y su objeto; también determinarán la experiencia del objeto, el lenguaje de esa experiencia y el ámbito en que se aplicará la acción derivada de ese conocimiento.

El tercer elemento consiste en expandir los intereses a un tercero: el interés emancipatorio, entendido como una nueva orientación básica que no corresponde a una tercera forma de desarrollo histórico al surgir del proceso mismo de autoconstitución de la sociedad humana. Su interés primario es librarse de la opresión causada por la naturaleza externa no dominada y por la naturaleza interna deficientemente socializada; el interés emancipatorio constituye la base y el punto de relación entre los intereses técnicos y prácticos, y se expresa en un tercer tipo de ciencias: las críticas. Estas atraviesan las ciencias naturales y prácticas porque constituyen una instancia de autorreflexión y de vinculación derivativa respecto al proceso de humanización. En definitiva, los intereses son racionales en cuanto no responden a necesidades empíricas, sino "que esas necesidades y esa relación dependen de la interpretación que de ellas hagan los hombres. Como toda interpretación pertenece a la dimensión comunicativa, la dimensión técnica... está empotrada en esta última. De allí la centralidad que Habermas otorga a la acción comunicativa" (Laso, 2004, p. 16); esta última categoría extiende y enriquece el concepto de intereses del conocimiento y permite relacionar de manera más profunda la teoría con la praxis. 
Las consecuencias de la concepción del interés emancipatorio como fuente y criterio de evaluación de los otros son profundas: entre las principales, se destaca el restablecer la relación entre ciencia y filosofía, esta última considerada ya no como reina, pero sí con un rol fundamental al interno de las ciencias. Las ciencias requieren de la filosofía para liberar el pensamiento de los estrechos márgenes del positivismo y desenmascarar la insuficiencia normativa del interés técnico respecto al proceso de autoconstitución humana.

La teoría de la acción comunicativa es otro de los puntales de la teoría habermasiana del conocimiento respecto a la cual establece una serie de distinciones explicitadas en la Tabla 3.

Tabla 3

Acciones comunicativas según Habermas

\begin{tabular}{|l|l|}
\hline \multicolumn{1}{|c|}{ Acciones } & \multicolumn{1}{c|}{ Relaciones con el mundo } \\
\hline Acción teleológica & $\begin{array}{l}\text { Concibe un solo mundo objetivo con el cual el actor puede establecer } \\
\text { dos relaciones: conocer estados de cosas existentes y traer a la exis- } \\
\text { tencia estados de cosas deseados. }\end{array}$ \\
\hline Acción estratégica & $\begin{array}{l}\text { Concibe un solo mundo, pero en interacción con otros agentes. Uso } \\
\text { del lenguaje como medio orientado al éxito y no al entendimiento. }\end{array}$ \\
\hline normas & $\begin{array}{l}\text { Concibe dos mundos: un mundo objetivo de cosas y un mundo so- } \\
\text { cial que consiste en normas institucionales que fijan reglas, roles y } \\
\text { valores. El actor se concibe como miembro de un grupo social al } \\
\text { que necesita para satisfacer sus necesidades. El individuo se disuelve } \\
\text { en la sociedad. }\end{array}$ \\
\hline Acción dramatúrgica & $\begin{array}{l}\text { Concibe tres mundos: además del mundo de las cosas y del mundo } \\
\text { social, incluye un mundo subjetivo al que solo el actor tiene acceso. } \\
\text { El actor interactúa y se comunica con otros actores para posicionar } \\
\text { su rol y su imagen. La sociedad se disuelve en el individuo. }\end{array}$ \\
\hline Acción comunicativa & $\begin{array}{l}\text { Concibe cuatro mundos: al mundo objetivo, social y subjetivo, agre- } \\
\text { ga el mundo del lenguaje mediante el cual los actores llegan a un } \\
\text { acuerdo en una acción orientada al entendimiento. }\end{array}$ \\
\hline
\end{tabular}

Elaboración de los autores a partir de Laso (2004, p. 17). 
Las acciones así concebidas se articulan en una doble dimensión: la dimensión instrumental, que comprende lo teleológico-estratégico; y la dimensión comunicativa, basada en la interacción por procesos cooperativos de interpretación de significados y valoraciones que requieren un cierto grado de comunidad en el mundo de la vida (Laso, 2004, p. 20). La acción comunicativa es la más importante de todas por ser constitutiva de la sociedad humana; la considera el fundamento de su filosofía de la racionalidad y ayuda a comprender la razón como una trama discursiva que articula las acciones de los individuos. A la vez, es un concepto crítico ya que denuncia "el carácter mutilado de la comunicación vigente en la sociedad contemporánea” (p. 21), así como otros aspectos característicos de la deshumanización como la instrumentalización del conocimiento y de las relaciones entre los individuos y el dominio suicida respecto al medioambiente. Denuncia, en suma, la hegemonía del interés instrumental sobre el interés práctico (comunicativo) y emancipatorio. La Tabla 4 expresa las relaciones entre las dimensiones, intereses y formas de conocimiento y acciones, según Habermas.

\section{La metateoría habermasiana}

La metateoría habermasiana se juega en dos escenarios. El primero profundiza antes que las diferencias las relaciones del conocimiento teórico con otras formas de conocimiento denominadas preteoréticas, vale decir, el sentido común o conocimiento no científico. El segundo prolonga y retoma la reflexión de Horkheimer para desarrollar la teoría dialéctica en contraposición con la teoría analítica. Veamos los puntos fundamentales de ambos desarrollos. 


\section{2}

Tabla 4

Dimensiones del desarrollo histórico de la sociedad según Habermas

\begin{tabular}{|c|c|}
\hline \multicolumn{2}{|c|}{ Dimensiones } \\
\hline Dimensión técnica & Dimensión social \\
\hline $\begin{array}{l}\text { Relaciones hombre-naturaleza. } \\
\text { Trabajo productivo y reproductivo. } \\
\text { Orientación básica: interés técnico (dominio } \\
\text { sobre la naturaleza). }\end{array}$ & $\begin{array}{l}\text { Relaciones entre los hombres. } \\
\text { Cultura y normas sociales. } \\
\text { Orientación básica: interés práctico (relacio- } \\
\text { nes y entendimiento entre los hombres). }\end{array}$ \\
\hline \multicolumn{2}{|c|}{ Aspectos cognitivos } \\
\hline $\begin{array}{l}\text { Interés técnico: ciencias empírico-analíticas. } \\
\text { Objeto de conocimiento técnico (manipula- } \\
\text { ción instrumental de la naturaleza). } \\
\text { Lenguaje fisicalista. } \\
\text { Ciencias naturales. }\end{array}$ & $\begin{array}{l}\text { Interés práctico: ciencias } \\
\text { histórico-hermenéuticas. } \\
\text { Objeto de conocimiento práctico (comuni- } \\
\text { cación entre individuos). } \\
\text { Lenguaje intencional. } \\
\text { Ciencias hermenéuticas. }\end{array}$ \\
\hline $\begin{array}{l}\text { Acciones instrumentales: acciones teleológi- } \\
\text { cas y estratégicas (medios y fines) enroladas } \\
\text { en la orientación técnica. }\end{array}$ & $\begin{array}{l}\text { Acciones orientadas por normas y roles } \\
\text { insertadas en la orientación práctica. }\end{array}$ \\
\hline \multicolumn{2}{|c|}{$\begin{array}{c}\text { Interés emancipatorio (o interés crítico) como orientación básica de la sociedad: } \\
\text { ciencias sociales críticamente orientadas. } \\
\text { Se identifica con el proceso de autoconstitución humana. } \\
\text { Base y fuerza derivativa de los intereses técnicos y prácticos. } \\
\text { Acciones orientadas al entendimiento, argumentación } \\
\text { y reconocimiento de validez de los actos de habla. } \\
\text { Guiadas por el interés crítico. }\end{array}$} \\
\hline
\end{tabular}

Elaboración de los autores a partir de Laso (2004, p. 14).

\section{Conocimiento teórico y conocimiento preteorético}

Habermas, a lo largo de un ensayo escrito en 1977 (1996, pp. 453 y ss.), establece que el sentido, entendido como el significado que los actores atribuyen a sus acciones, es una condición ontológica de la sociedad humana en cuanto producida y reproducida por sus miembros que hace posible las acciones y la intersubjetividad. La 
realidad social, como mundo social de la vida, está simbólicamente preestructurada; es preteorética y, en rigor, no necesita de la teoría para acceder al sentido. Además, es una realidad que habla y se comunica. Esta ontología conecta el conocimiento con la producción y las relaciones sociales, y entiende las ciencias sociales como acceso comprensivo - hermenéutico - a su ámbito de objetos "porque encuentra en él procesos de entendimiento a través de los cuales y en los cuales ese ámbito objetual se ha constituido previamente, es decir, con anterioridad a toda intervención teorética" (1996, p. 457). Por tanto, no son las teorías las que estructuran al mundo o logran entenderlo sobre el supuesto de que existe un vacío de significados. El mundo ya está estructurado por el significado que le atribuyen sus actores.

En este contexto, toda teoría se entiende como materialización o expresión simbólica de la realidad, una metáfora que interpreta la realidad de tal manera que, en rigor, todas las ciencias son hermenéuticas, incluso las naturales. Por tanto, cualquier teoría debe ser interrogada a partir del sentido, el referente teorético básico, pues todas las teorías son interpretaciones de la realidad. No obstante, en las ciencias sociales tiene lugar una doble hermenéutica, pues el investigador interpreta los enunciados del actor social (el mundo social habla) y a paso seguido los compara con los suyos mediante una relación compleja entre teoría, realidad y lenguaje. En cambio, en las ciencias naturales ocurre un tipo de hermenéutica diversa, de una sola vía, ya que se trata de un mundo sin enunciados, que no habla. Habla el investigador e interpreta lo que él dice del mundo.

La pertenencia del investigador a un mundo de la vida trae consigo presupuestos del lenguaje y de la acción de tal manera que la teoría del investigador también es anterior a la realidad social y, además, la realidad social está constituida con anterioridad a la teo- 
ría, es decir, es precientífica. El científico se topa con una realidad construida por los actores, por los sentidos que ellos han generado; a la vez, todo científico participa de un proceso de entendimiento inmerso en una situación comunicativa que lo vuelve interlocutor participante de su objeto.

Habermas asume innovadoramente la distinción entre teoría y sentido común. Comienza afirmando que ambas poseen estructuras similares, pero considera que solo la relación entre ellos produce el saber de la realidad sociocultural según un método que relaciona los saberes preteoréticos y los teóricos, de tal manera que los segundos logren traducir e interpretar los primeros. Así, el científico, al ser parte del mundo social de la vida, participa tanto del conocimiento teórico como preteórico, a la vez que forma parte de la sociedad, del objeto que constituye su investigación; con ello, trasciende también la dualidad sujeto-objeto de conocimiento propia del positivismo. El científico "tiene en cierto modo que pertenecer al mundo social de la vida cuyos ingredientes trata de describir. Pues para describirlos tiene que entenderlos; para entenderlos, tiene en principio que poder participar en su generación; y la generación presupone pertenencia" (Habermas, 1996, p. 468).

Las consecuencias metodológicas de esta manera de ejercer la teoría son muy profundas y las resumimos en tres ideas fundamentales e interconectadas entre sí:

En primer lugar, las teorías tratan de conocer manifestaciones simbólicas, tanto si se trata de las teorías del investigador cuanto de las preteorías del campo, tanto de las acciones sociales cuanto de sus relaciones.

En segundo lugar, el conocimiento teórico de la realidad social accede a las manifestaciones simbólicas mediante la participación del 
investigador en el mundo social que busca comprender. Por lo tanto, la investigación social es una experiencia comunicativa que implica diálogos para interrogar el sentido y supone participación en un proceso de entendimiento. No se trata de empatía, sino de participación. La investigación es una actitud realizativa (performativa) de un participante en la comunicación cuyo logro a alcanzar consiste en iluminar desde dentro los significados de las producciones humanas, revelando la posición del actor. Si el investigador no participa — real o virtualmente - del grupo que quiere conocer, no puede comprender. La realidad simbólicamente preestructurada le resulta impermeable e ininteligible al observador ya que la observación, como proceso autorreferenciado y controlable, no es suficiente para comprender las realidades sociales y del espíritu, las cuales están simbólicamente predeterminadas. Es válida si va acompañada por una comprensión del sentido en el contexto de una experiencia dialogal y comunicativa (p. 460).

En tercer lugar, también el científico social hace uso de un saber del que intuitivamente dispone como lego cuando incorpora sus teorías del mismo modo que la gente posee el sentido común, al incorporarlas en su mundo preteorético. Mientras no identifique su saber preteórico y no establezca qué papel desempeña en la investigación, no puede controlar las consecuencias de su participación en el grupo cuyas acciones quiere comprender. Por tanto, debe realizar el tremendo esfuerzo de clarificarse a sí mismo qué supuestos teóricos no consentidos o no conscientes interfieren en su investigación. Habermas incorpora el sentido común, o conocimiento preteórico, como elemento esencial del método y lo incluye, además, en el lado del investigador y en confrontación con sus teorías. Las teorías también pueden actuar como sentido común e imponer sus reglas del juego, sin que el investigador sea consciente de ello. 


\section{6}

\section{Teoría analítica y teoría dialéctica}

En otro ensayo (Habermas [1963] 1996, pp. 21 y ss.) también referido a la comprensión de la vida social, construye la distinción entre teoría analítica y teoría dialéctica para esbozar los rasgos adicionales de su metateoría. En el contexto de la comprensión de la realidad social, define las teorías como "esquemas de ordenación que construimos a voluntad en un marco sintácticamente vinculante. Tales esquemas resultan útiles para un ámbito especial de objetos cuando la diversidad de lo real se ajusta efectivamente a ellos" (p. 22). Así, todo saber es mediatizado por categorías del entendimiento de tal modo que las teorías no constituyen copias de lo real como pretende el positivismo, sino instrumentos de interpretación de la realidad; ni siquiera podemos suponer que las teorías se correspondan ontológicamente con la realidad. En el sentido de que las teorías no expresan la realidad, se acerca a Popper, no obstante lo cual, se distancia de él en el punto de establecer que el saber no es mera opinión.

El segundo aspecto de la metateoría habermasiana retoma la tradición proveniente de Horkheimer basada en una doble distinción: la teoría analítica, encaminada al dominio sobre la naturaleza, y la teoría dialéctica cuyo fin es comprender el sentido de las acciones humanas. La diferencia entre ambas modalidades se aprecia en la Tabla 5.

La teoría dialéctica, signada por la comprensión, es la alternativa al programa positivista y, por lo tanto, más cercana a la hermenéutica y a la interpretación, rasgo característico de las ciencias sociales y de la educación. A partir de tal apreciación de las ciencias sociales, se distancia definitivamente de Popper cuya propuesta se basa en una cierta homogeneidad metodológica entre ciencias naturales y sociales, pues ambas invocan el mismo rigor lógico que establece leyes y modelos, no interpretaciones (Popper, 2005, pp. 201 y ss.). 


\section{7}

Tabla 5

Contrastación entre teoría analítica y teoría dialéctica según Habermas

\begin{tabular}{|l|l|}
\hline \multicolumn{1}{|c|}{ Teoría analítica } & \multicolumn{1}{c|}{ Teoría dialéctica } \\
\hline $\begin{array}{l}\text { Su modelo son las ciencias naturales } \\
\text { basadas en operaciones hipotéticas } \\
\text { deductivas. }\end{array}$ & $\begin{array}{l}\text { Explica la sociedad y las acciones humanas según } \\
\text { la explicación hermenéutica de sentido. } \\
\text { Las categorías se determinan progresivamente. }\end{array}$ \\
\hline Se basa en la observación controlada. & Parte de la conciencia de los sujetos. \\
\hline $\begin{array}{l}\text { Plantea leyes restrictivas que pretenden } \\
\text { validez universal. }\end{array}$ & $\begin{array}{l}\text { Plantea leyes de validez comprehensiva sin validez } \\
\text { general pero que aprenden una situación histórica } \\
\text { en su conjunto. }\end{array}$ \\
\hline $\begin{array}{l}\text { El valor de conocimiento se materializa } \\
\text { en las leyes empíricamente contrasta- } \\
\text { das con capacidad de proponer técni- } \\
\text { cas aplicadas a la práctica para con- } \\
\text { trolar procesos sociales como si fueran } \\
\text { naturales. }\end{array}$ & $\begin{array}{l}\text { Se deja interpelar por el objeto de conocimiento } \\
\text { para plantear sus problemas a partir del objeto } \\
\text { Une la reflexión teórica con la práctica social; la } \\
\text { dimensión instrumental con la dimensión crítica. }\end{array}$ \\
\hline $\begin{array}{l}\text { Cosifica la vida social y objetiva su reali- } \\
\text { dad enajenando su conocimiento de los } \\
\text { intereses del investigador. }\end{array}$ & Los intereses son constitutivos del acto de conocer. \\
\hline
\end{tabular}

Elaboración de los autores a partir de Habermas (1996).

\section{Comentarios e implicaciones}

La propuesta de Horkheimer pone en escena la centralidad del sujeto intelectual, que hace de sus opciones y voluntad de transformación el punto de arranque para construir la teoría crítica sobre otras condiciones del pensamiento tales como la delimitación de un objeto o la determinación de las condiciones del conocimiento. El rol del sujeto intelectual en relación con los movimientos emancipatorios, además, es un tema clave respecto al cual Horkheimer favorece la imagen de un teórico de vanguardia no solo independiente de los partidos y movimientos, sino en permanente pugna con ellos, de 


\section{8}

cierta manera un personaje solitario y en minoría también respecto a los teóricos tradicionales.

El rol del crítico no se limita a expresar y describir el pensamiento de una clase ni tampoco su función es avalarlo, ya que las diversas formas de autoconciencia no expresan necesariamente la verdad sobre esa clase ni implican de por sí emancipación; cualquiera de dichas tareas es legítima solo en razón de su eficacia transformadora. Por ello, la relación del intelectual con las clases sociales será siempre conflictiva, y la teoría, cuya intencionalidad es apurar las formas sociales nuevas, debería ser ejercida, incluso, como "crítica agresiva" nada contemplativa ni condescendiente (p. 247).

Como el proletariado no genera espontáneamente teoría, el conflicto surge también de la visión de conjunto más amplia que puede aportar el teórico al leer la realidad y determinar medios y fines para asegurar la "coherencia interna" de los procesos. Surge así el peligro de que el intelectual crítico se constituya en intelligentsia, forma de ejercicio teórico que, aunque situada en el escenario de las luchas sociales, no deja de ser abstracta y formal, autónoma y desligada de la praxis, cuya tendencia natural es imponer sus convicciones a la conciencia general. Por ello, "la vanguardia necesita la perspicacia en la lucha política, no la información académica acerca de su pretendida posición" (p. 253).

El pensamiento de Horkheimer ha sido tan discutido como ampliado y desarrollado. Uno de sus puntos débiles radica en la pretensión de criticar una totalidad desde otra, como si fuera posible reducir la diversidad de ejercicios teóricos y de saberes a cualquiera de las dos posibilidades en un momento en que resulta obvio el carácter multiforme del pensamiento. Asimismo, tanto a él como a Adorno se les reprocha que su influencia en América Latina ha sido tan poderosa 
que ha impedido pensar "todo lo que de nuestra realidad y cultura no cabía ni en su sistematización ni en su dialéctica” (Barbero, 1998, p. 69); sin embargo, no dudamos de su utilidad para advertir, en primer lugar, que toda teoría es producto de relaciones — no exclusivamente de producción — y del trabajo, y que inevitablemente está unida a una praxis; en definitiva, el conocimiento mismo es una práctica social históricamente determinada. Finalmente, a partir de que todo pensamiento contiene al mismo tiempo el secreto y la protesta del presente (lo real no es racional, pero debe serlo), es posible comprender que, antes que la objetividad, la razón emancipatoria es el alimento de la teoría. Por lo tanto, ninguna teoría es neutral y la razón instrumental no puede constituirse en el horizonte final de su ejercicio.

Si evaluáramos a Popper según las categorías analíticas de Horkheimer, no tardaríamos en advertir que su propuesta es la antítesis perfecta por su negación de la historia y de las utopías. Popper, sin duda, ejemplifica a la perfección la teoría tradicional porque postula un sujeto abstracto basado en la relación invariable respecto a la realidad histórica y social y a su objeto; ya porque se fundamenta en un procedimiento autorreferenciado según las leyes de falsación, o porque su enfoque en la solución de problemas perpetúa la estructura social y hace de la ciencia un generador de valores de utilidad y no de transformación. No obstante, debemos recordar que la crítica de Horkheimer no deslegitima ni anula el ejercicio de la ciencia tradicional, sino su pretensión de erigirse en criterio absoluto y autónomo respecto a la transformación social y la humanización.

Si bien Habermas ha sido blanco de cuestionamiento y críticas porque supuestamente representa la ideología de la democracia liberal que idealiza el consenso y la acción comunicativa por encima de las determinaciones y exclusiones reales del poder; y porque los movimientos sociales consideran que el conocimiento interpretativo 
no cubre las expectativas de la emancipación (Walsh, 2007). No obstante, el aporte de Habermas diseña un método claro para superar la distinción dual sujeto-objeto, raíz de todas las formas de pensar que constituyen la base de relaciones hegemónicas y excluyentes del tipo hombre-mujer, hombre-naturaleza, civilizado-salvaje, etc., según denuncian los ideólogos de los movimientos sociales.

Las aplicaciones para el ejercicio teórico se relacionan con la teoría dialéctica, cuya idea central consiste en que los datos y las categorías con las que pretendemos acercarnos a la comprensión de la realidad social "vienen estructurados por el plexo de la totalidad social" (Habermas, 1996, p. 23); por lo tanto, el sujeto de conocimiento, la teoría y el trabajo científico no son puntos de partida, sino parte integrante del objeto de conocimiento, de la totalidad social que es necesario conocer. Al estar inmersos el investigador y sus teorías en el objeto que se busca conocer, ninguna de las categorías que usa le deben "permanecer externas" (p. 23) y en ningún momento deben actuar desde el sentido común, sin sentir la necesidad de controlar sus alcances y restricciones.

Tal afirmación fundamental conlleva profundas consecuencias para nuestra actitud cognoscitiva respecto a la realidad social: no se trata de acercarse a ella para observar y registrar regularidades empíricas o solucionar problemas (como pretende Popper), pues tales esquemas no pueden penetrar la estructura social y, de cierta manera, la falsifica; además, la teoría se torna irrelevante porque es invalidada por el objeto (p. 23).

La teoría dialéctica debe ser entendida también como una actitud epistémica profunda que supera la lógica de exclusión de los opuestos para vincularlos complementaria y relacionalmente. Así, la actitud dialéctica no enfrenta el saber teórico con los saberes preteo- 
réticos para anularlos e invalidarlos; los incorpora en una relación generadora de conocimientos de la misma manera que no contrapone y relaciona los factores subjetivos de la investigación (el género y el mundo emotivo del investigador) con los objetivos.

En relación con la naturaleza y la trama de la vida amenazada en el planeta, el pensamiento crítico es relevante porque denuncia la racionalidad instrumental de la ciencia y la técnica condicionadas al sometimiento de la naturaleza y la aniquilación de la vida. Hans Jonas (1903-1993) asume la tarea de traducir para la ética el contraste entre teoría tradicional y teoría crítica, y postula la ética de la responsabilidad (1995) basada en evidenciar los principios de la ética tradicional y de la ética crítica (Juncosa, 2013, pp. 239-244). La ética crítica parte de una serie de transformaciones respecto a la noción de naturaleza y la manera de entender lo humano como parte de lo viviente, a la vez que evidencia los siguientes supuestos de la ética tradicional que alimentan relaciones de dominio respecto a lo viviente:

1) neutralidad ética de la actividad humana respecto a la naturaleza; 2) carácter antropocéntrico de la ética tradicional que desconoce las relaciones con la naturaleza y lo viviente; 3) concepción de la naturaleza como realidad dada, incompleta o imperfecta sin la intervención humana y, por lo tanto, objeto necesario de su acción. Así, la visión tecnológica se instaura desde una visión optimista de sus propias posibilidades sobre un trasfondo pesimista respecto a la naturaleza, considerada como algo dado sin valor y disponible a cualquier apuesta de mejoría. (Lander, 1994, pp. 138 y 143) (Juncosa, 2013, 240-241)

La ética crítica concibe la naturaleza como totalidad de lo viviente, y es una realidad autónoma y completa en sí misma que no requiere de la acción humana para perfeccionarse; está habitada por finalidad e intencionalidad propia, por valores y motivaciones. A su 
vez, el hombre es un organismo que integra lo viviente y lo orgánico constituye su subjetividad. Las consecuencias de tales puntos de partida apuntan a desbloquear la ética de las relaciones interpersonales para hacer de la naturaleza "el polo obligado de la acción ética" (p. 241), acción que busca asegurar no solo la supervivencia humana, sino también el sostenimiento de la vida en todas sus formas. Por lo tanto, no existen acciones éticamente neutrales respecto al sostenimiento de la vida. Entre las consecuencias epistémicas de concebir al hombre como organismo viviente consta "la superación de toda forma de dualismo (noúmeno-fenómeno, mente-cuerpo, sociedadnaturaleza, reino de la necesidad-reino de la libertad, etc.) porque enajena y escinde del ser" (p. 241).

\section{El paradigma del pensamiento complejo de Edgar Morin: la teoría como sistema abierto de ideas}

En la vida de Edgar Morin (París, 1921) confluyen, de manera tan temprana como intensa, la militancia política y la producción académica. A los 15 años fue miembro de los anarquistas catalanes y en 1941 se unió al Partido Comunista Francés, en su condición de judío, para integrarse a la resistencia contra la invasión nazi. Luego de ser expulsado del partido en 1951, por sus críticas a los sistemas que conformaban el socialismo real (el estalinismo, el régimen de Tito y de China), formó parte de los Comités de Intelectuales por la Paz contra la Remilitarización de Alemania y la guerra en Argelia (1954) y se involucró desde las aulas de la Universidad de Nanterre en las revueltas estudiantiles de Mayo del 68. Este recorrido da cuenta de su militancia reflexiva pero también de su aversión hacia los sistemas cerrados de ideas como las ideologías y los dogmas.

Entre los contactos importantes con otros filósofos y sociólogos, cabe destacar la relación, en los años 60, con Roland Barthes 
(1915-1980) y Cornelius Castoriadis (1922-1997), quienes influirán decisivamente en su forma de concebir el sujeto, el pensamiento y la comunicación. Su huella está presente en la convicción de que es posible entender mejor problemas contemporáneos como el cine, la literatura, la muerte y la subjetividad mediante la integración de múltiples perspectivas integradas que confluyen en la mirada humanista. Las experiencias decisivas que contribuirán a consolidar su epistemología ocurrirán por esos mismos años, durante los cuales incursionará en el territorio de las ciencias "duras", en especial, en las ciencias del cosmos, la física y la ecología.

Para ello resultó clave su paso por el Instituto Jonas Salk de Estudios Biológicos (California), a instancias del biólogo francés y Premio Nobel Jacques Monod (1910-1976), donde profundizó las implicaciones de la revolución biológica en las ciencias sociales y humanas. Inmediatamente, a partir de los aportes del zoólogo británico Gregory Bateson (1904-1980), integró los principios de la teoría general de sistemas, de la cibernética y de la teoría de la información, al mismo tiempo que asimiló, entre otros, la propuesta del físico de origen soviético Ilya Prigogine (1917-2003) de una ciencia abierta al caos y a la incertidumbre, así como las del matemático John von Neumann (1903-1957) y del cibernetista Heinz von Foerster (1911-2002), relacionadas con el "azar organizador" y la "autoorganización”.

Finalmente, durante su estadía en la Universidad de Berkeley, se abrió al paradigma del nuevo pensamiento ecológico y sus implicaciones para una nueva epistemología. Semejante itinerario consolida la orientación inter y transdisciplinaria, y hace posible la identificación de los dos principios fundamentales que regirán su propuesta denominada pensamiento complejo: la globalidad y la reorganización, surgidos de la interacción de las humanidades con las ciencias naturales y cibernéticas. 
La obra de Morin es extensa pero la de mayor relevancia epistemológica para la metateoría es, sin duda, El método, que consta de seis tomos. El cuarto, Las ideas. Su hábitat, su vida, sus costumbres, su organización (1992), expone los fundamentos de su metateoría y constituye la principal fuente de este apartado. Los supuestos ontológicos y políticos del pensamiento complejo, en cambio, los hemos tomado fundamentalmente de su obra La mente bien ordenada (2001), que desarrolla muy claramente la visión de la realidad y del individuo, así como sus implicaciones para el conocimiento.

\section{Compromisos ontológicos, éticos y políticos del pensamiento complejo}

La visión de la realidad asumida por Morin se basa en el isomorfismo (del griego iso: 'igual'; morfé: 'forma') o correspondencia compleja entre universo, vida y pensamiento, según la visión emergente de la segunda revolución científica, operada a partir de los años 60 por la ecología, las ciencias de la tierra, la cosmología y la cibernética. Estas no conciben su objeto como un sector o parcela de la realidad; su objeto es el sistema, entendido como un todo organizador. En consecuencia, la visión de la realidad que contribuyen a modelar corresponde a la de una entidad compleja que se autoorganiza y cuyos elementos establecen relaciones de diverso tipo como las interacciones, las retroacciones y la interretroacciones a partir de las cuales "el todo y las partes se entreproducen y se entreorganizan" (2001, p. 33). En consecuencia, es posible comprender diversos fenómenos económicos, sociales, políticos o psicológicos —incluido el pensamiento - considerados sistemas o totalidades a partir de la dinámica de los organismos biológicos: la bio-lógica.

La noción de sujeto se construye sobre la misma base (2007, pp. 170 y ss.), una de cuyas coordenadas lo define como ser autóno- 
mo, autonomía que no es absoluta sino relativa a y en interacción con su entorno biológico, cultural y social. La segunda interrelaciona complementariamente el carácter de individuo (la consistencia del ser biológicamente único) con el de sujeto (las tensiones con la especie que representa, los aspectos universales). Así, la dimensión cognitiva es esencial para la vida del sujeto, pues todo proceso de intercambio con el entorno, en el fondo, se puede traducir en términos de intercambio de información. En el sujeto el conocimiento es un acto de cómputo, sí, pero con relación a sí mismo y, por lo tanto, es un acto de cómputo irreductible, no maquinal.

La noción de sentido es otro de los aspectos relevantes (2007, pp. 18 y ss.) para la epistemología de Morin y puede ser entendida de dos maneras: en tanto teleología, o la orientación histórica general impresa en la realidad y atribuida a una instancia providencialista, externa y anterior; y en tanto telenomía, o necesidad inherente al ser mismo de atribuirse finalidades y asumir la subjetividad. Con respecto a la primera, coincide parcialmente con Popper en cuanto a la imposibilidad de reconocer la existencia de cursos de la historia de tipo providencialista que actúan como marcos totales. Desde este punto de vista, el sentido no reina en las cosas; de hecho, tanto en la macro como en la microfísica reina la arbitrariedad y la deflagración en mayor medida que el orden y la armonía; asimismo, tal como lo demuestra la evolución, la vida también procede según itinerarios multidireccionales e inesperados en los que la conciencia no parece ser más que un resultado aleatorio y casual antes que un desemboque esperado.

La telenomía, en cambio, es un rasgo ontológico del ser humano cargado de consecuencias para la existencia y el pensamiento, la más importante de las cuales consiste en que el sentido, al mismo tiempo que frágil, es una emergencia y una construcción; no es un 


\section{6}

hecho dado y anterior, sino producido por el conocimiento y la subjetividad sobre el trasfondo del no-sentido teleológico. La emergencia de los sentidos en un marco de no-sentido implica consecuencias epistemológicas profundas, entre las más importantes está la legitimidad de la hermenéutica y la necesaria apertura del pensamiento a la incertidumbre, a lo inconcebible e ininteligible, donde toda comprensión o propuesta de sentido, en el fondo, es una apuesta abierta (2007, p. 165).

Un último aspecto de la visión sobre la historia que refuerza la relación orden-desorden es la teoría de la acción (ecología de la acción) expresada en dos principios fundamentales (2001, p. 117): 1. Toda acción, una vez lanzada, entra en un juego de interacciones y retroacciones que pueden ocasionar resultados desviados de los fines o inesperados; 2. Las consecuencias últimas de la acción son impredecibles. La incertidumbre y la impredecibilidad son, por lo tanto, condiciones normales de la vida y del conocimiento.

Además, la mirada histórica de Morin atribuye al presente el carácter de crisis profunda y global que es resultado de una manera de pensar. Por ello, Morin propone una nueva forma de pensar que se encarna en su programa de reforma del pensamiento, reforma "no programática, sino paradigmática, que concierne a nuestra aptitud para organizar el conocimiento" (2001, p. 22). Precisamente será la bio-lógica, o lógica de lo viviente, la fuente de los principios-guías para pensar bien que encauzarán su reforma del pensamiento y sentarán las bases del pensamiento complejo (complexus: lo que está tejido con), y cuya potencialidad consiste en permitir captar las partes por el todo $y$, viceversa, reconocer y tratar realidades solidarias a la vez que conflictivas, comprender los fenómenos según las múltiples dimensiones que los constituyen, y por último, respetar lo diverso y reconocer lo único. Los siete principios son los siguientes (pp. 123 y ss.): 
1. El principio sistémico u organizativo que consiste en relacionar el conocimiento de las partes con el conocimiento del todo, recuperando el principio de la lanzadera de Pascal. ${ }^{18} \mathrm{El}$ todo confiere a las partes el carácter de emergencias y las dota de cualidades que serían inexistentes si se las considera individualmente.

2. El principio hologramático según el cual no solo la parte se encuentra en el todo, sino donde el todo está inscrito en la parte, tal como la totalidad del patrimonio genético está presente en la célula individual o la sociedad (sus normas, lenguaje y cultura) está presente en el individuo.

3. El principio del bucle retroactivo (feedback) es el conjunto de retroacciones autorreguladoras de un organismo que permite su homeostasis o adaptación a las presiones y demás del sistema. Al reelaborar las transformaciones del entorno, el feedback se contrapone a la causalidad lineal porque da lugar a nuevas direcciones y opciones imprevistas que hacen posible la persistencia del organismo. En su forma negativa, el principio del bucle retroactivo reduce las desviaciones; en su forma positiva, es un mecanismo amplificador.

4. El principio del bucle recursivo que supera la noción de regulación por la de autoproducción y autoorganización. Se trata de un bucle generador, según el cual los productos y efectos son a la vez productores y causantes de lo que los produce. Así, es cierto que los individuos son producto de la cultura, pero, a la vez, la producen y transforman con su práctica.

5. El principio de autonomía-dependencia (auto-eco-organización), según el cual los seres vivos son seres autoorganizadores e incluyen interacciones con el medio para mantener su autonomía mediante intercambios de energía. Para los seres vivos

18 "Considero imposible conocer las partes sin conocer el todo, y tampoco conocer el todo sin conocer particularmente las partes". Citado en Morin (2001, p. 123). 
en general esos intercambios ocurren con el entorno geoecológico; para los humanos, con la cultura. Los intercambios energéticos implican la dualidad muerte-vida en la constitución misma de los procesos de regeneración.

6. El principio dialógico permite asumir racionalmente la inseparabilidad de nociones contradictorias y unir dos principios o nociones que deben excluirse mutuamente, pero que son indisociables en una misma realidad. Así, el cosmos integra dialógicamente la secuencia orden-desorden-organización, integración propia también del mundo biológico como humano. El pensamiento, por ejemplo, integra tantos procesos objetivos como subjetivos, reorganizándolos permanentemente.

7. El principio de la reintroducción del conocedor en todo conocimiento, según el cual todo conocimiento es una reconstrucción-traducción por un espíritu-cerebro en una cultura y un tiempo dado.

\section{La metateoría del pensamiento complejo}

Lo medular de la metateoría de Morin se desarrolla a lo largo del tomo IV de El método. Las ideas. Su hábitat, su vida, sus costumbres, su organización, en el cual describe el mundo de las ideas como si se tratara de un mundo biológico, donde las ideas son seres dotados de vida que se reproducen en una atmósfera propia y poseen sus propias reglas de evolución. El presente apartado describirá el "ecotipo" del mundo de las ideas (la noosfera), la estructura interna de las teorías y su relación con seres de otro tipo que habitan el mismo mundo. Luego, establecerá el lugar del lenguaje y la lógica, a los que considera polimáquinas de la teoría; finalmente, concluirá con el análisis de las posibilidades de articulación teórica explícitas (las disciplinas) o subyacentes (los paradigmas). 


\section{Las teorías: entidades logomorfas de la noosfera}

Tal como sucede con los seres biológicos, las ideas tienen su propio ser y existencia; son medios (instrumentos) al mismo tiempo que elementos constitutivos de un mundo llamado noosfera, o tercer mundo, análogo al mundo de las ideas de Popper, en el que habitan las cosas del espíritu, productos culturales, nociones, teorías, conocimientos científicos, etc. Las ideas, aunque son producidas y dependientes, adquieren "una realidad y una autonomía objetivas" (Morin, 1992, p. 112), de tal manera que "hay que considerar la vida de las ideas, no ya en el sentido metafórico y vago del término 'vida', sino enraizando este sentido en la teoría de la auto-eco-organización de lo viviente" (p. 114). La Figura 3 muestra el lugar y las relaciones de la noosfera con el resto de estratos de la antroposfera (p. 126).

Figura 3

Ubicación de la noosfera en el contexto de los estratos de la antroposfera

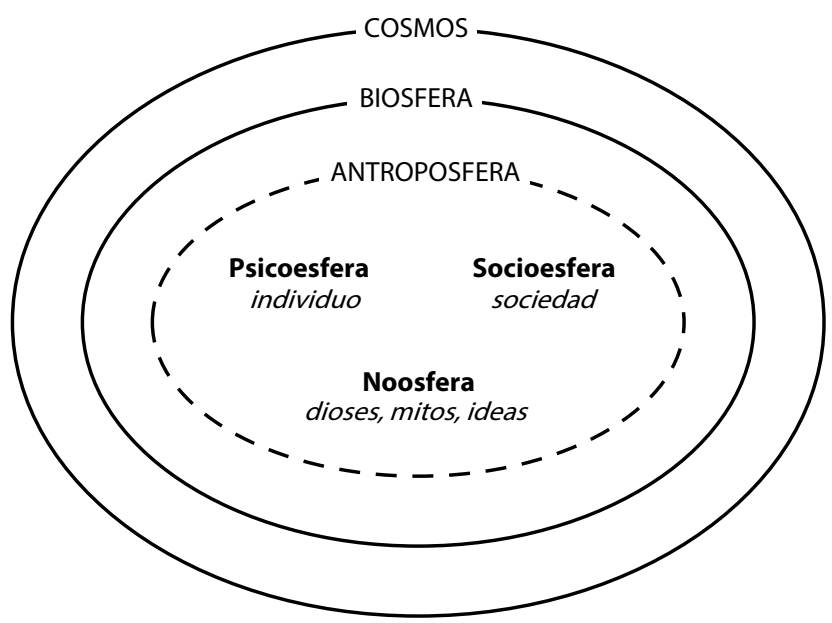

Tomado de Morin (1992, p. 126). 
Estos estratos, una trinidad inmersa articulada simbióticamente y englobada por la naturaleza (biosfera) y el cosmos, son la psicoesfera, la socioesfera y la noosfera. La psicoesfera es el mundo de los espíritus-cerebros individuales, fuente de las representaciones y causa de su consistencia. La socioesfera hace posible la concretización de las representaciones y que estas tengan vida por medio de la cultura, producida por las interacciones entre espíritus-cerebros y continente del lenguaje, el saber, las reglas lógicas y paradigmáticas. La noosfera, o tercer reino, es un constituyente objetivo de la realidad humana cuya demografía consiste de "seres materialmente enraizados, pero de naturaleza espiritual” (Morin, 1992, p. 118), cuyo soporte físico son las inscripciones cerebrales y los intercambios energéticos. Los tres mundos son simbióticos, ya que cada uno vive y requiere del otro y que cada instancia es medio y fin para el otro. Las simbiosis entre los mundos no siempre son sanas y emancipatorias: a veces, el mundo de las ideas impone sus reglas al resto, como en el caso de la técnica o de la ideología.

Los entes de la noosfera, al mismo tiempo que viven en la psicoesfera y la socioesfera, son necesarios para la regeneración de cada uno de ellos. A partir de una de las tipologías propuestas por el autor, los entes noológicos son de dos clases: seres gaseosos, que se disipan con la misma facilidad con que emergen (sueños); y seres sólidos, de carácter estable, los cuales incluyen las entidades cosmo-bio-antropomorfas (mitos, religiones, genios, espíritus, dioses), y las entidades logomorfas (doctrinas, teorías, filosofías, sistemas de ideas). Entre las entidades cosmo-bio-antropomorfas y las logomorfas existe una ruptura ontológica. Todas estas entidades conforman tres reinos fundamentales: los dioses (seres religiosos), los productos culturales (seres estéticos) y las ideas (teorías, ideologías, creencias). 
Según la metáfora biológica, los seres del espíritu, como todo ser vivo, se organizan, garantizan su existencia, crean su medio y reproducen desdoblándose "a través de mil redes de comunicación humana, a través del discurso, la educación, el adoctrinamiento, la palabra, el escrito, la imagen" (p. 129). Asimismo, se regeneran sin cesar según sus propias reglas de evolución al pasar por diversas fases: de los mitos arcaicos a las grandes religiones de la Antigüedad y de los tiempos modernos; de la proliferación de ideologías y las ideas abstractas hasta el saber técnico y el universo imaginario de los productos culturales (literatura, novela, cine y televisión).

La noología es la ciencia que hace posible comprender las cosas del espíritu como entidades objetivas, así como sus principios de organización; asume que sus entes poseen una existencia propia, diversa a lo concreto, sin que ello implique reducir su grado de realidad a reverberaciones de la psique (psicologismo) o de la sociedad (sociologismo); estos entes son autónomos (eventualmente soberanos) y enraizados en la psique y la sociedad. Para comprender los entes noológicos es necesario integrar tres ángulos: el noológico, el psicológico y el sociológico de tal manera que sea posible no solo concebirlos como productos o constructos, sino también como productores de sentido, ya que las religiones, los productos culturales y las ideas son a la vez autónomos y dependientes. Por lo tanto, no constituyen solo instrumentos al servicio de la interpretación de la realidad, también poseen sus patologías pues tienen el poder de poseer y de constituirse en soberanos como ocurre cuando los seres humanos se someten a las ideologías o cuando los entes mitológicos pretenden sustituir la realidad al oscurecer su dimensión de instrumentos.

Lo importante de la propuesta de Morin es que, al concebir las ideas y, por ende, las teorías, como entes con vida propia, trasciende su carácter de instrumentos del conocimiento. Las ideas no solo pue- 


\section{2}

den ser usadas y producidas, también poseen el poder de imponer a los espíritus individuales y a la cultura sus propias reglas y, más a menudo de lo que creemos, se apoderan de ellos. Por ello, la dialéctica producto-productor es inherente a las teorías. La Figura 4 da cuenta de los seres de la noosfera y de la ubicación del Reino de las ideas en el que se desarrollan los seres logomorfos que denominamos teorías.

Figura 4

Seres de la noosfera

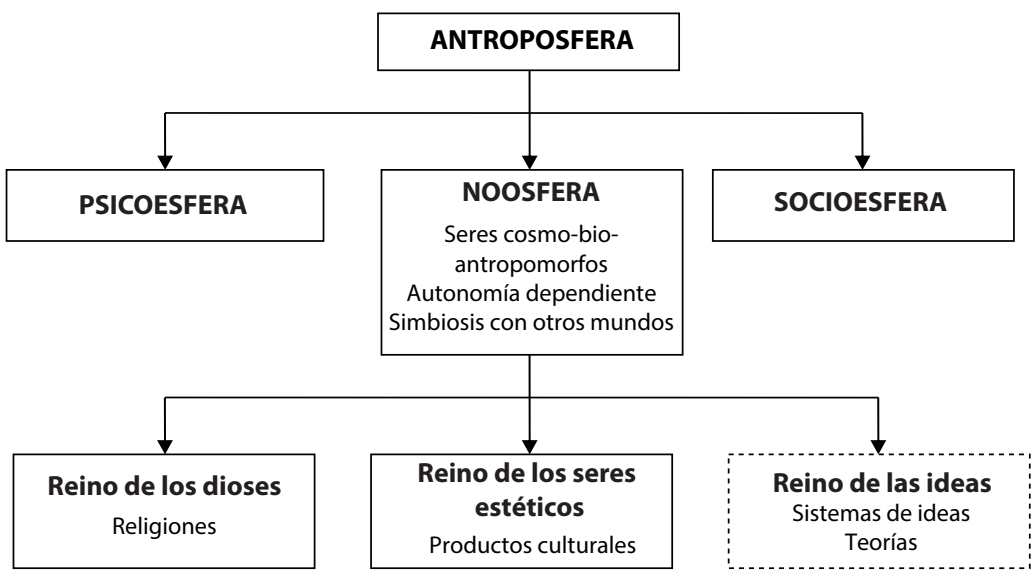

Elaboración de los autores a partir de Morin (1992).

\section{El Reino de las ideas y sus diversos sistemas: organización interna y tipología}

Son dos los niveles fundamentales de organización al interno de un sistema de ideas. Según el primero, todo sistema de ideas está constituido "por una constelación de conceptos asociados de forma solidaria y cuya disposición es establecida por los vínculos lógicos... en virtud de axiomas, postulados y principios de organización subyacentes... un sistema tal produce en su campo de competencia enun- 
ciados que tienen valor de verdad $y$, eventualmente, predicciones sobre todos los eventos que en él deben manifestarse" (Morin, 1992, p. 132). En un segundo nivel Morin afirma - siguiendo el aporte de Lakatos - que todo sistema de organización de ideas comporta dos dispositivos: uno de autoorganización (abierto) y otro de autodefensa (cerrado). El dispositivo de autoorganización está constituido por un núcleo polinuclear merced al cual se produce y reproduce a sí mismo. El núcleo duro, conformado por postulados indemostrables y principios ocultos (paradigmas), es una suerte de zona ciega que tiende a ser refractaria a la autocrítica respecto a sus fundamentos. El núcleo determina principios y reglas de organización de las ideas, los criterios de legitimación de la verdad del sistema a la vez que activa mecanismos de selección de los datos relevantes y de apoyo o de ignorancia en relación con lo irrelevante. El dispositivo de autodefensa activa funciones inmunológicas de protección y autodefensa que eliminan todo aquello que tiende a perturbar y desajustar el sistema. Según esta concepción, todo sistema de ideas se protege y defiende de las degradaciones procedentes del exterior al mismo tiempo que se alimenta de ellas. Todo sistema de ideas

posee cierto número de caracteres auto-eco-organizadores que aseguran su integridad, su identidad, su autonomía, su perpetuación; le permiten metabolizar, transformar y asimilar los datos empíricos que dependen de su competencia; se reproduce a través de los espíritus/ cerebros en las condiciones socioculturales que le resultan favorables. Puede tomar la suficiente consistencia y potencia como para retroactuar sobre los espíritus humanos y sojuzgarlos. (1992, p. 141)

En este marco la racionalización es un tipo de respuesta defensiva que resiste a las críticas y refutaciones externas, opuesta a la racionalidad. Si bien ambos procedimientos buscan la coherencia, la racionalidad es abierta a lo real y la racionalización integra lo real a su propia lógica. El autoritarismo y la agresividad "ortodoxa”, junto 
con la racionalización, es otro de los peligros inminentes de todo sistema de ideas, merced a la ceguera cognitiva que lo constituye.

Según el criterio de cierre y apertura, los sistemas de ideas a cuya forma de organización es posible reducir todas las demás son de dos tipos: las teorías (privilegian la apertura) y las doctrinas (privilegian el cierre). Ambos no constituyen realidades del todo separadas; más bien, los límites son difusos y porosos, al punto de que toda teoría tiende a convertirse en doctrina (el dogma es la intención del pensamiento); si bien estos sistemas tienden a cerrarse sobre sí, en la teoría esta tendencia no es irreductible. La Figura 5 muestra la primera clasificación del mundo de las ideas basada en las dinámicas de cierre y apertura porque, luego, Morin propondrá otra más histórica y compleja:

Figura 5

Sistemas del Reino de las ideas

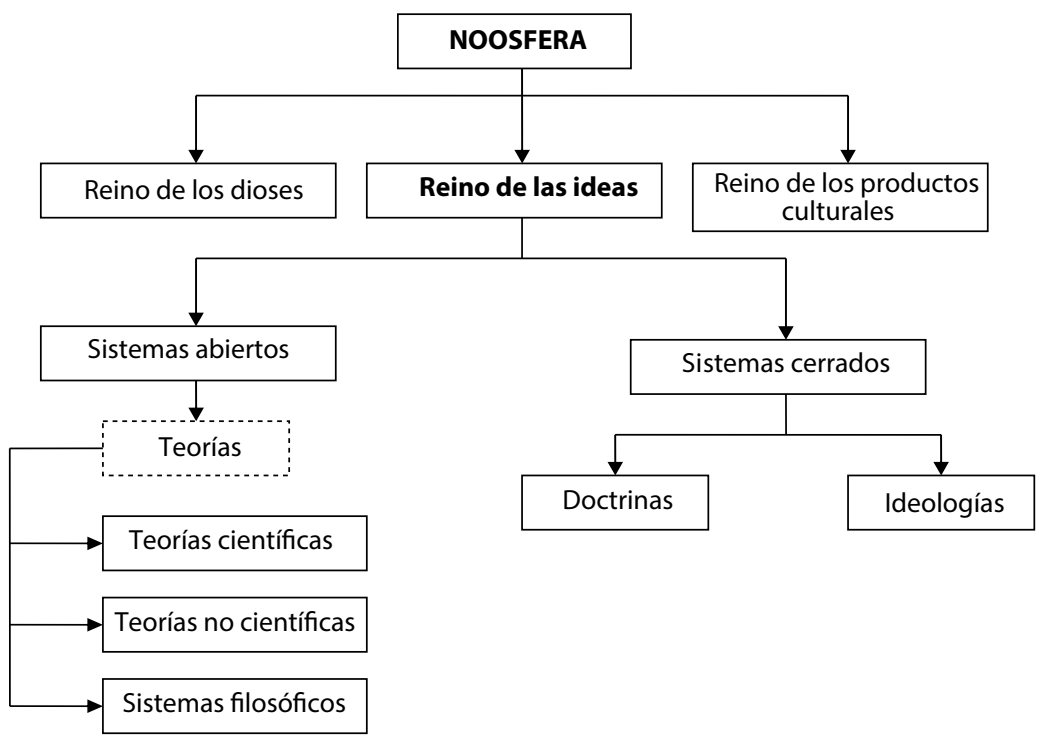

Elaboración de los autores a partir de Morin (1992). 
La segunda tipología se origina en el territorio de una visión histórica de la cultura europea como laboratorio noológico de la razón. Así, el desarrollo concreto de la noosfera filosófica europea evidencia, sobre la distinción básica arriba descrita, tres tipos diferentes de sistemas de ideas (Morin, 1992, pp. 141 y ss.): a) las teorías científicas, cuyo campo de pertinencia se limita al conocimiento; b) los sistemas normativos que unen hechos y valores; y c) los sistemas explicativos universales, con una evidente vocación a conformar marcos explicativos globales.

Las doctrinas, los sistemas filosóficos y las ideologías son sistemas normativos; las grandes doctrinas, los grandes sistemas filosóficos y las grandes ideologías forman parte de los sistemas explicativos universales, siendo el de Hegel el más grandioso de todos. De alguna manera los sistemas filosóficos y, por extensión, los grandes sistemas filosóficos, pueden considerarse teorías en tanto que las ideologías son formas doctrinarias de pensamiento. La Figura 6 da cuenta de esta nueva tipología, atenta al desarrollo histórico del Mundo de las ideas.

Figura 6

Las teorías y su relación con los sistemas normativos y explicativos

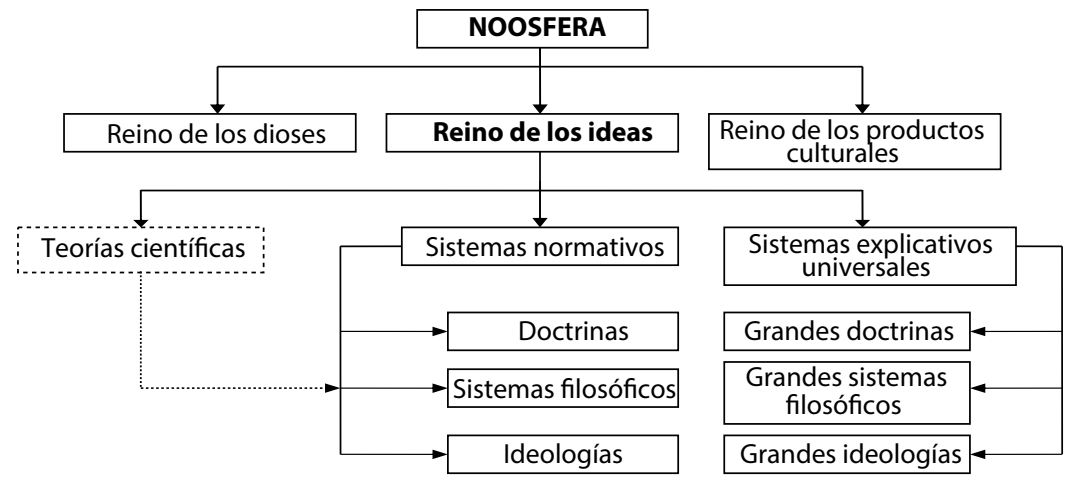

Elaboración de los autores a partir de Morin (1992). 


\section{6}

\section{Las polimáquinas de las teorías: el lenguaje y la lógica}

La relación del lenguaje y la lógica con la teoría han sido temas clave de la epistemología, pues algunas escuelas y orientaciones han reducido el pensamiento teórico a una realidad sobredeterminada por uno u otro elemento. Morin retoma este problema clásico y redimensiona la lógica y el lenguaje, asignándoles la función de polimáquinas de la teoría; vale decir que les confiere el rol de dimensiones esenciales, sin las cuales las teorías no podrían comunicarse ni articularse, a la vez que preserva su relativa autonomía y su carácter de realidades mutuamente irreductibles.

El lenguaje: es imposible concebir las teorías sin los textos ni los discursos que las expresan. Sin embargo, la consideración del lenguaje es crucial no solo como modalidad expresiva de los sistemas de ideas; también el que lo concibamos de una u otra manera nos posiciona respecto a sus alcances y límites con relación al conocimiento. Según la propuesta del pensamiento complejo (Morin, 1992, pp. 149 y ss.), el lenguaje forma parte de la realidad noológica y es esencial para la vida de la noosfera ya que de él depende la organización de los seres del espíritu, entre ellos, las teorías. La vida del lenguaje es un dato evidente, pues se autoconstruye, cambia, se transforma. Como sucede con otros sistemas, es una realidad autoeco-organizada, autónoma y dependiente a la vez, al punto de que puede ser considerado un instrumento o bien una realidad humana clave. El lenguaje es un organismo complejo, polivalente y polifuncional, con fines tanto descriptivos como performativos. Morin (pp. 167 y ss.) lo define como polimáquina, e identifica tres maquinarias o subsistemas articulados a otras máquinas y sistemas: a) máquina de doble articulación (sonidos y sentidos); b) máquina asociada a la maquinaria cerebral (lógica y analógica); y c) máquina engranada a la máquina cultural. 
La tesis esencial se resume en que el conocimiento no se reduce al lenguaje; por lo tanto, es ilegítimo trascendentalizarlo y dotarlo de una realidad hegemónica a tal extremo que resulte posible subsumir el problema del pensamiento en el del lenguaje. Los argumentos se despliegan en dos direcciones: la primera consiste en la referencialidad del lenguaje; la segunda, en el carácter contextual del sentido. En efecto, debido a que implica una referencia necesaria a algo diverso de él mismo y que "la autonomía-centralidad del lenguaje no excluye ni el espíritu/cerebro humano que lo produce, ni el sujeto que es locutor, ni las interacciones culturales y sociales en las que adquiere consistencia y ser" (1992, p. 166), es necesario situarlo sin disolverlo ni reificarlo, incorporándolo en una red de interdependencias y relaciones productivas.

Con respecto al sentido, Morin establece su importancia como resultante de la relación entre significado y significante, al mismo tiempo que en virtud de condición y finalidad del lenguaje; no obstante, advierte que no es posible concebirlo de manera tal que nos lo imaginemos atrapado o encapsulado en los elementos lingüísticos; más bien, el sentido implica y llama a relacionar el lenguaje con una realidad mucho más amplia que él mismo y considerar una imbricación de elementos diversos como el contexto, la situación y el marco conceptual en juego. Por añadidura, el sentido también hace referencia y dice interdependencia a una cadena de otros sentidos en los que se inscribe. Por lo tanto, no es posible disolver el pensamiento en la interrogación por el sentido circunscrito al discurso ni en la semántica del lenguaje.

Por último, el autor relaciona conocimiento y lenguaje para traer a colación el conocido hecho del desdén y desprecio de los académicos respecto al lenguaje común y ordinario como expresión no solo de la necesidad que nace del rigor terminológico inscrito en 
el método científico; se trata, además, de un hecho de poder, de la "voluntad de reservar para los iniciados, expertos o especialistas las competencias fundamentales para tratar todos los problemas" y de la tendencia a "privar a los ciudadanos del derecho al conocimiento" (Morin, 1992, p. 176).

La lógica: es la segunda maquinaria — la "maquinaria cognitiva formal" - conformada por dos sistemas: la realidad compútica (el aspecto formal y las normas) y la realidad noológica, asociada pero no reducida al lenguaje. En tanto tal, es la armadura formal de un sistema de ideas. Morin (pp. 177 y ss.) aplica a la lógica la misma advertencia que al lenguaje: en tanto realidad noológica, a la vez autónoma y dependiente, es capaz de servir como instrumento de los diversos sistemas de ideas o apoderarse hegemónicamente del mundo de las ideas. La lógica no puede constituirse en un juez supremo ni autónomo del conocimiento. La lógica, cuyo correlato es la certeza racional, es un tipo especial de racionalidad fuertemente condicionada por la obediencia controlada a principios, axiomas y operaciones lógicas; en este sentido, constituye el carácter fundamental de las teorías. En tanto que sistemas lógicos, los rasgos fundamentales de las teorías racionales son dos: a) coherencia: por un lado, los elementos están estrechamente unidos entre sí, según los procedimientos lógicos de deducción-inducción; por otro, los enunciados obedecen al principio de no contradicción; b) relación verificable y no arbitraria respecto al mundo objetivo al que se aplican.

El lugar de la lógica se define a partir del análisis crítico de dos de sus desarrollos históricos: la lógica identitaria (basada en el $O r$ ganon de Aristóteles) y la de quienes la absolutizan, como Ludwig Wittgenstein (1889-1951), Rudolf Carnap (1891-1970) y el Círculo de Viena (al que perteneció Popper). Los términos de su propuesta final incluyen no el desconocimiento, pero sí una opción que 
aboga por el debilitamiento de la lógica. En contraste a las posiciones arriba descritas, el pensamiento complejo aboga por una lógica que no se baste a sí misma, que deba ser considerada tan solo como un sistema formal, no autosuficiente, necesitado de un contexto no formal y de rango superior para determinar sus principios. Son dos las condiciones de la nueva lógica: la necesidad de incorporar la contradicción como método y la constitución de un metapunto de vista que se instaure como criterio. Veamos ambos aspectos.

A partir de los descubrimientos físicos del siglo XX, como la indeterminabilidad cuántica, el principio de incertidumbre, la noción contradictoria de partícula y del quantum, Morin concluye que estos no solo afectan los principios básicos de la lógica clásica, sino que han dado lugar a la denominada Revolución epistémica de Bohr, según la cual dos proposiciones contrarias pueden ser también complementarias. Así, se fortalece una visión aporética del ser al punto de que toda contradicción es indicio y anuncio de lo verdadero y, por lo tanto, sin contradicción no hay progresión en el conocimiento. La contradicción es valorada como la norma de oro del pensar: "Pensar con/contra la contradicción es la tarea del pensamiento complejo" (Morin, 1992, p. 202). Por lo tanto, toda limitación debe ser apreciada como un camino al conocimiento y toda teoría debe valorar las contradicciones fuertes sobre las débiles; es decir, aquellas que tengan valor heurístico, las que abren horizontes de preguntas sobre las que los cierran; las que poseen el potencial de cuestionar constructos y contradicciones que se juegan sobre la doble montura de lo lógico y lo real sobre las que son unidimensionalmente lógicas.

Inspirado en el filósofo y matemático Bertrand Russell (18721970), el pensamiento complejo valora como principio el metapunto de vista, según el cual todo sistema conceptual no es autosuficiente e incluye cuestiones a las que únicamente puede responder desde el 
exterior mismo de su sistema. Así, lo que organiza una teoría no es la lógica, sino una metalógica que reivindica el lugar del sujeto sin que este se diluya en ella. Toda teoría solicita un punto de observación sobre sí misma ubicado más allá de sí misma, desde donde es capaz de examinar sus propias condiciones de emergencia y de ejercicio, sus condiciones lógicas y noológicas, así como las condiciones históricosocio-culturales en las que se desarrolla (Morin, 1992, p. 209). El metapunto de vista obra en virtud de un procedimiento sin fin, basado en las operaciones sucesivas de problematización y reproblematización. Lo plausible, valor epistémico que prima sobre lo certero, se instaura como mecanismo de discernimiento y asume una actitud de relatividad (no de relativismo) entendida como apertura y reconocimiento de la complejidad: "la complejidad puede ser descompuesta, pero no siguiendo los axiomas que excluyen la contradicción” (p. 209).

Finalmente, de la mano del isomorfismo y correspondencia compleja entre pensamiento, vida y universo anteriormente señalados, Morin asume que "si lo real es complejo, la lógica es incompleta" y tanto la teoría como la realidad son abiertas. En consecuencia, "la existencia viviente es alógica, sublógica, metalógica” (p. 209). A partir de la dialógica (lógica debilitada), la propuesta de Morin establece, para el proceso de construcción de teorías y su análisis, criterios de juicio basados en una serie de reivindicaciones: la circularidad yo-tú-sociedad-cultura, el primado del sujeto, la referencialidad con la realidad y el sentido, la relación sujeto-objeto. Así, toda teoría es un sistema ideacional abierto, falible y complejo.

\section{El gobierno oculto de las teorías: los paradigmas}

Como hemos visto, la teoría admite varios niveles de articulación intra e interteóricos para cuya comprensión Morin reelabora puntos de vista complementarios provenientes de varias tradiciones. 
En primer lugar, recupera muy genéricamente y casi sin entrar en detalles la postura axiomática para dar cuenta de los aspectos más visibles y superficiales de la articulación intrateórica, entendida como la constelación de conceptos asociados de forma solidaria según una disposición lógica que concatena axiomas, postulados y principios de organización subyacentes. En segundo lugar, asume con mayor desarrollo la visión historicista de Lakatos para describir el segundo nivel, más profundo, en el que todo sistema de organización de ideas integra dos dispositivos: el núcleo duro o de autoorganización (abierto) y el cinturón protector o de autodefensa (cerrado) cuyas dinámicas combinadas explican las continuidades y resistencias, así como las transformaciones teóricas. Finalmente, incorpora ampliamente la explicación historicista de Kuhn para explicar el tercer nivel, el más profundo y decisivo de todos, en el cual las teorías se articulan entre sí según esquemas subyacentes denominados paradigmas o principios de conocimiento que las gobiernan de manera oculta e implícita y condicionan su desarrollo.

Veamos ahora los detalles y alcances de la articulación paradigmática entre teorías, aspecto al cual Morin le confiere particular interés (1992, pp. 216 y ss.) y en el que recupera de la manera más radical una propuesta que el mismo Kuhn no se sentía ya capaz de sostener, vencido por las críticas contra la vaguedad e imprecisión del término. Morin no recupera al concepto de paradigma a pesar $d e$, sino precisamente por su vaguedad e imprecisión, rasgos que dan perfecta cuenta del tipo de poder propio de una instancia que gobierna de manera subyacente y oculta todo sistema de ideas incluida la teoría en su calidad de fundamento primero, fundador y nuclear. Su definición de paradigma es el siguiente:

Un paradigma contiene, para cualquier discurso que se efectúe bajo su imperio, los conceptos fundamentales o las categorías rectoras de 
inteligibilidad al mismo tiempo que el tipo de relaciones lógicas de atracción/repulsión (conjunción, disyunción, implicación u otras) entre estos conceptos o categorías. (1992, p. 218)

Esta definición implica un triple carácter: semántico, ideológico y lógico. El carácter semántico consiste en determinar la inteligibilidad y otorgar sentido a los sistemas de ideas; ideológicamente, impone los tipos de asociación, eliminación y la selección de la organización de las ideas; lógicamente, determina las operaciones lógicas rectoras (p. 218).

Para Morin la noción de paradigma incluye y especifica otras como la de episteme de Michel Foucault (1926-1984) ${ }^{19}$, y los tipos epistemológicos de Magoroh Maruyama. La noción de episteme es más profunda y amplia por referirse a los fundamentos del saber en general y recubrir la totalidad del campo cognitivo de la cultura. No obstante, y a diferencia del paradigma, la relación episteme-cultura planteada por Foucault es simple ya que cada cultura articula su saber en torno a una sola de ellas. Los tipos epistemológicos, según Maruyama, son formas de pensamiento que condicionan de manera diversa la percepción, la causalidad y la lógica, y cada uno determina su propio paisaje mental que organiza y confiere visibilidad a lo que debe ser pensado, que presenta aquello que puede estar al "alcance de la mente".

El interés de la propuesta de Maruyama ${ }^{20}$ radica — igual que la episteme - en su generalidad pues se aplica no solo al conocimiento,

19 Foucault desarrolla el concepto de episteme (2005) y la trata como una formación discursiva con efectos de poder. Otra de las categorías importantes de Foucault en relación con la episteme es la de orden del discurso que profundiza la intencionalidad de los discursos también en función del poder.

20 Maruyama desarrolla su propuesta de los paisajes mentales en el artículo Mindscapes and Science Theories (1980), del cual ofreceremos una descripción detallada en el capítulo III. 
sino también a la ética, la estética y la religión. Ambas propuestas se refieren, por lo tanto, a grandes paradigmas que controlan el campo cognitivo en su totalidad y a toda la cultura; si bien la noción estricta de paradigma es más acotada, se inscribe en toda forma posible de conocimiento y se aplica a todos los sistemas noológicos en general. La operativa y el funcionamiento del paradigma se expresa en sus caracteres esenciales, reagrupados temáticamente (Morin, 1992, pp. 222 y ss.), según su rol en los procesos de conocimiento teórico, en la configuración de la realidad, y las relaciones entre los paradigmas.

En relación con los procesos de conocimiento y los sistemas de ideas, el paradigma no es falsable y está fuera del alcance de cualquier proceso de validación o verificación; son falsables, en cambio, las teorías que emanan de él. Si bien el paradigma confiere autoridad a los axiomas, estos a su vez lo legitiman. El paradigma es un criterio de reconocimiento de problemas y establece las exclusiones o inclusiones de los datos y preguntas que está dispuesto a reconocer según criterios de simplificación, reducción, disyunción o complejidad. Es el organizador invisible del núcleo organizacional visible de la teoría y crea la evidencia ocultándose a sí mismo, de tal manera que genera la ilusión de obedecer a los hechos o a la lógica. Si bien la invisibilidad lo hace invulnerable, todo paradigma está sujeto a cambios y a transformaciones, y las grietas paradigmáticas se evidencian primero por su lado visible y aspectos secundarios: las teorías y los sistemas de ideas.

Con respecto a la realidad, así como el paradigma niega carácter real a lo que excluye, genera la sensación de realidad a lo que incluye en su enfoque. Además, determina la mentalidad o visión del mundo, en términos de los mindscapes (paisajes mentales), de tal forma que un cambio de paradigma se ramifica en sucesivas transformaciones de la producción artística, la política, la moral o la religión. Finalmente, en lo que a la relación entre paradigmas respecta, 


\section{4}

es posible la coexistencia de varios paradigmas en el seno de una cultura, pero siempre habrá incomunicabilidad y antinomia entre ellos, así como entre las teorías y los sistemas que controlan.

Los paradigmas se inscriben en la organización cognitiva, en la organización noológica, en los procesos lingüísticos y lógicos, en la cultura y en la sociedad. Estas últimas instancias son determinadas por estos del mismo modo que aquellas determinan los paradigmas (Morin, 1992, p. 235). Así como pueden convivir varios paradigmas a la vez en el seno de un ambiente cultural o civilización de manera pacífica o violenta, muchas veces, ideas en apariencia contrarias o irreductibles pueden obedecer a un mismo paradigma. Morin aporta un muy buen ejemplo de ello a partir de las teorías que relacionan cultura y naturaleza; así, algunas postulan que la naturaleza es una instancia por entero reductible a la cultura en el sentido de que la naturaleza no puede ser entendida sino por ser intervenida y habitada por la cultura; otras, en cambio, aducen que la cultura es producto de la naturaleza y un reflejo de los constreñimientos que el medio proyecta sobre la sociedad. Ambas posibilidades que en la superficie son rivales y responden a paradigmas diversos en lo profundo son la expresión de un mismo paradigma: de aquel que excluye y opone ambas instancias para convertir a cada una en un producto de la otra en lugar de relacionarlas según vínculos de mutua implicación.

Por lo tanto, y partir del ejemplo mencionado, podemos entender que un paradigma no se traduce ni expresa tanto en una serie de contenidos o aserciones cuanto en una manera de articularlas y relacionarlas entre sí, ya sea de manera excluyente o disyuntiva, relacional, dual o tripartita, entre otras posibilidades. Se trata más bien de un modo de pensar, de una lógica que condiciona en lo profundo las posibilidades de relación. Los grandes paradigmas que Morin describe (1992, pp. 226 y ss.) son fundamentalmente dos: el gran 
paradigma de Occidente y el paradigma emergente. Veamos muy resumidamente los aspectos esenciales de cada uno.

El gran paradigma de Occidente se consolida con la concepción cartesiana de la realidad, la cual separa y secciona los órdenes de lo real en dos mitades irreductibles y separadas: sujeto-objeto, alma-cuerpo, espíritu-materia, cualidad-cantidad, sentimiento-razón, etc., al punto que entre tales dualidades se instaura una relación disyuntiva, de mutua exclusión, que se expresa en todos los ámbitos de una cultura esquizofrénica y desintegrada. Podemos entender así la separación entre las humanidades y la práctica científica, así como la relación de dominio del hombre respecto a la naturaleza como expresión del mismo paradigma. La vida cotidiana también se ve afectada por la partición del universo en dos cuando la religiosidad, el arte y la literatura y la esfera de la vida privada y de los sentimientos en general funcionan como contrapeso no integrado o desahogo del yugo de la objetividad a la que nos somete la ciencia o los procesos económicos, productivos o burocráticos:

el gran paradigma está presente [...] no solo en la sociedad (disyunción entre la organización tecno-buro-econocrática y la vida cotidiana), en la cultura (disyunción entre cultura de las humanidades y cultura científica), sino también en los psiquismos y en las vidas, suscitando los pasos, como saltos cuasi cuánticos, del mundo de los sentimientos, pasiones, poesía, literatura, música, al mundo de la razón, el cálculo, la técnica. (Morin, 1992, p. 234)

El gran paradigma de Occidente da vida a la ciencia clásica cuya expresión cumbre ha sido el positivismo lógico debido a su ilusión de sustentarse en dos ejes incuestionables: por un lado, la lógica; por otro, la realidad. En la ciencia clásica el principio de disyunción separó las ciencias entre sí y, en su interior, unas disciplinas de otras "fragmentando su objeto en el tejido solidario de lo real" (1992, p. 
231). El principio de exclusión va asociado a otros principios subsidiarios que han regido la ciencia clásica: el primero de ellos es la visión mecanicista de la realidad que la reduce a un orden determinista simple; el segundo es el principio de reducción, el cual da lugar a una visión atomista de la realidad "que conmina a desintegrar las entidades globales y sus organizaciones complejas en provecho de las unidades elementales que la constituyen, y que se convierte en fuente y fundamento de toda inteligibilidad" (p. 231).

En este punto, Morin retoma la visión kuhniana de las revoluciones científicas y las entiende como transformaciones paradigmáticas que ocurren a nivel de la manera de pensar y concebir la relación entre los varios aspectos de la realidad, de tal modo que tales transformaciones obligan a reorganizar las teorías y reconsiderar los fenómenos en función del nuevo paradigma.

Finalmente, Morin diagnostica fisuras y agrietamientos en el gran paradigma de Occidente — el cual todavía continúa muy operativo - habida cuenta de los siguientes síntomas: a) cada vez más se mira hacia los sistemas, la totalidad y la complejidad, poniendo las cosas en relación con su entorno; b) el sujeto se introduce en el objeto en lugar de excluirse y separarse de él, es decir, los investigadores se cuestionan sus teorías y métodos e incluye su propia subjetividad; c) cuestionamiento a la lógica deductiva-identitaria. No obstante, y a pesar de los crujidos y de los cuestionamientos no se da paso todavía a una nueva lógica ni se establecen ligazones reales entre los diversos órdenes de la realidad, a pesar de los deseos de interdisciplinariedad. Se vive una crisis, eso sí; pero para instaurar el nuevo paradigma hace falta una reforma en cadena del entendimiento. De momento, vivimos en la incertidumbre y tan solo balbuceamos el nuevo paradigma en medio de una batalla conformada por una sucesión de 
múltiples e imprevistos combates planteada no entre ideas sino entre nuevas formas de organizarlas (Morin, 1992, pp. 240 y ss.).

\section{La articulación manifiesta entre las teorías:} inter, multi, poli $y$ transdisciplinariedad

Para la epistemología de la ciencia, la cuestión de la inter o la transdisciplinariedad remite, en el fondo, a establecer cómo se organizan e integran las teorías entre diversos marcos disciplinarios, en la cual, la disciplina constituye - a diferencia del paradigma - la forma visible y manifiesta de articulación interteórica. Con respecto a la articulación entre teorías que pertenecen a espacios disciplinarios diversos, el aporte de Morin es sumamente relevante y dotado de un potencial crítico notable; la tesis que le sirve de fundamento es la siguiente: la superación de los límites de la disciplina es la condición indispensable para el desarrollo del conocimiento teórico; tal superación se alcanza mediante el desarrollo de distintas formas de relación entre los diversos dominios disciplinarios o mediante la articulación creativa en un sistema teórico común.

Entendemos como disciplina el conjunto de teorías que se refieren a un ámbito de la realidad. Las teorías no agotan las disciplinas y estas están constituidas por varias de ellas según relaciones de diverso tipo: complementariedad, rivalidad total o parcial, hegemonía y de presuposición (Gianella, 2003, pp. 50 y ss.). Con respecto a la articulación entre teorías que pertenecen a espacios disciplinarios diversos, el aporte de Morin es sumamente relevante y dotado de un potencial crítico notable. La tesis esencial consiste en que el conocimiento teórico es posible solo si se superan los límites de la disciplina, ya sea para desarrollar distintas formas de relación entre los dominios disciplinarios, ya para articularlos en un sistema teórico común. Por lo tanto, el encierro disciplinario no solo es una 
patología cognitiva: es la negación del conocimiento que nace de la mutilación de la realidad en parcelas. Por ello, toda disciplina está atravesada por relaciones ecológicas con otras disciplinas, y admite múltiples maneras de interacción y retroacción. No se niega la disciplina, pero sobre la base de su interdependencia y apertura a la globalidad, emanadas de la complejidad constitutiva del dominio que cada una se propone conocer.

Veamos cómo Morin da cuenta de las relaciones que trascienden el encierro disciplinario. En primer lugar (2001, pp. 148 y ss.), evidencia las dinámicas de la disciplina, su tendencia a la autonomía y a generar fronteras, fundadas en la tradición universitaria decimonónica y enraizadas en la manera en que la sociedad en su conjunto concibió el trabajo y la productividad según el criterio de hiperespecialización propio de la era industrial. Tal modelo produce una estrategia crucial para la institucionalización del saber: la disciplina, la cual, si bien comporta ventajas como la capacidad de determinar un objeto de conocimiento no trivial y sus dominios, así como las competencias, el lenguaje y los conceptos que conformarán el marco de abordaje, también implica riesgos: la hiperespecialización del investigador y la cosificación del objeto de conocimiento como realidad autosuficiente y aislada, sin conexiones ni solidaridades teóricas, metodológicas o terminológicas con otras realidades. De esa manera, "el espíritu hiperdisciplinario va a convertirse en un espíritu de propietario que prohíbe cualquier incursión ajena en su parcela de saber" (p. 148). La superación de la hiperespecialización disciplinaria forma parte del desafío científico constitutivo, a su vez, de un proyecto cognitivo más amplio que incluye otros desafíos, como el cultural y el cívico (pp. 18 y ss.), desafíos que trasladan a sus respectivos escenarios la necesidad de superar diversos niveles de partición de la realidad y del conocimiento. 
El desafio cientifico, por tanto, busca superar el encasillamiento, la partición y la hiperespecialización del saber y de las disciplinas por medio del pensamiento contextual y complejo, más atento a las interrelaciones y abierto a la incertidumbre. El desafio cultural persigue superar la bipartición de la cultura alimentada por el saber humanista y el saber científico. El uno genérico, integrador y amplio; el otro, aplicado a escenarios separados y ámbitos específicos pero incapaz de pensarse a sí mismo y de incluir el destino humano en su horizonte. Esta partición los nutre de mutuas suspicacias y amenaza la consistencia y vigencia de ambas formas de mirar al mundo.

Por último, el desafío cívico apunta a superar el debilitamiento de la responsabilidad y de la solidaridad que surge de la renuncia a la globalidad y de la invisibilidad de los lazos orgánicos que ligan al individuo con su ciudad y conciudadanos. El déficit democrático lesiona también el derecho al conocimiento ocasionado por su apropiación en pocas mentes y por los mecanismos de accesibilidad condicionada, según el cual se vuelven inaccesibles los conocimientos globales y accesibles los compartimentados. Por ello, el programa cívico de Morin se cristaliza en la democracia cognitiva.

La historia de la ciencia (2001, pp. 149 y ss.) proporciona algunos ejemplos de contravención del espíritu hiperdisciplinario como la visión extradisciplinaria y las intromisiones y migraciones interdisciplinarias. La visión extradisciplinaria es propia de los iluminados que no se aferran a los límites inhibidores de la disciplina que profesan para mirar los datos de nuevas maneras. Es el caso de Wegener, meteorólogo, quien, al interpretar los mapas continentales a partir de las coincidencias entre sus contornos, elaboró la teoría de la deriva de los continentes. Las intromisiones y migraciones interdisciplinarias explican la circulación de las nociones y teorías por campos disciplinarios que no son propios a los cuales fecundan y potencian 
como, por ejemplo, la traslación de la noción de información, propia de la realidad social, al campo de la biología donde conformó el concepto de código genético. Asimismo, se transfieren no solo conceptos sino también esquemas cognitivos enteros como, por ejemplo, los presupuestos semióticos de Jacobson en la antropología estructural de Claude Levi-Strauss.

Otras formas de relación planteadas en términos de actitudes epistémicas programáticas son la inter, la multi, la poli y la transdisciplinariedad. La interdisciplinariedad es la forma elemental de asociación entre las ciencias y consiste en enfrentar un problema de investigación desde varias perspectivas disciplinarias a la vez, sin interacciones entre sus teorías y métodos, sino mediante la suma de aportes independientes como sucede, por ejemplo, cuando se busca comprender el alcoholismo desde la psicología profunda, la genética y la antropología.

La multidisciplinariedad es más compleja y consiste en el proceso mediante el cual, en razón del tipo de proyectos y objetos de conocimiento multicompetentes, así como de la complejidad inherente a ciertos campos de investigación, algunas disciplinas deben, forzosamente, superar sus límites disciplinarios y complejizar las competencias del investigador. Es el caso de la historia, la ciencia multidisciplinaria por excelencia, y del perfil multidisciplinario del historiador que integra la antropología, la literatura, la estética, las ciencias políticas o la urbanística, entre otras disciplinas.

La polidisciplinariedad es una forma de asociación de disciplinas en función de un objeto de estudio que les es común y que todas contribuyen a delimitar. También se da cuando las disciplinas construyen solidariamente nuevos marcos metodológicos en función de tal objeto. 
La transdisciplinariedad, por último, es actuada por esquemas cognitivos que al mismo tiempo que trascienden las disciplinas las pueden atravesar, generando rupturas disciplinarias y articulaciones imprevistas para unir ámbitos en apariencia disjuntos. El ejemplo es la biología molecular respecto a la astrofísica: ambas se han transdisciplinarizado a partir de la inclusión del interrogante de la vida en el universo, y generaron nuevas hipótesis y esquemas cognitivos que las trascendieron y determinaron nuevas maneras de concebir el problema.

\section{Comentarios e implicaciones}

La influencia de Morin ha sido muy profunda en varios escenarios de la reflexión latinoamericana debido a su rol como titular de la Cátedra Itinerante "Edgar Morin” sobre Pensamiento Complejo, creada por la Unesco en 1999 y a numerosos cursos dictados en universidades de Bolivia, Perú, México y Brasil, así como en varias sedes de la Facultad Latinoamericana de Ciencias Sociales (Flacso). En Ecuador, su aporte es seguido muy de cerca por no pocas experiencias educativas relacionadas con educación formal y popular en contextos de desarrollo y, de manera particular, por las nuevas universidades indígenas, pues su refutación de la lógica disyuntiva basada en oposiciones va muy de la mano de la autocomprensión que los indígenas tienen de su propio conocimiento, orientado a integrar las contradicciones e incorporar la ritualidad y el mito.

Morin nos enseña que para acceder a lo real y dialogar con el mundo son necesarias las ideas y es imposible prescindir de ellas, pues son mediadoras de nuestra relación con lo real. De hecho, estamos poseídas por ellas, pero también podemos intentar poseerlas, a fin de superar las ideologías, las doctrinas y las teorías reductoras y mutilantes. Las teorías científicas de alguna manera pueden civilizar el mundo de las ideas, pero a condición de que sean abiertas 
y acepten el principio de biodegradabilidad, reconociendo también sus carencias, en especial la incapacidad para mirar reflexivamente su núcleo paradigmático, la tendencia a disociar hecho y valor $\mathrm{y}$, por último, la ineptitud de pensarse a sí mismas que surge del ocultar y rechazar los problemas filosóficos (1992, p. 254). Se requiere, en suma, "una nueva generación de teorías abiertas, racionales, críticas, reflexivas, autocríticas, aptas para auto-reformarse, auto-revolucionarse incluso" (p. 256).

La salida para recuperar y reencauzar el ejercicio de las teorías científicas es establecer un campo de comunicación y de mutua apertura con las teorías epistemológicas, filosóficas y éticas. Así como no podemos prescindir de la esfera científica, tampoco podemos prescindir de la filosofía ni del mito, el arte o la novela, estrategias cognitivas que conviven y se interrelacionan necesariamente.

Sobre la base de la incertidumbre Morin identifica tres tareas adicionales del conocimiento (1988, pp. 169 y ss.). La primera consiste en establecer un diálogo con lo irracionalizado y lo irracionalizable, es decir, con aquello que no entra en los cánones de la lógica aristotélica. La segunda tarea se refiere a la investigación, respecto a la cual el conocimiento ejerce un patrullaje por medio de los conos de sombra y de lo que escapa a la comprensión, invocando otras formas de entendimiento como, por ejemplo, las metáforas y la poesía. Por último, la tercera tarea es evidenciar la ignorancia, los agujeros negros que constituyen el pensamiento. El conocimiento, así entendido, se previene de toda pretensión de saber absoluto, definitivo o irrefutable: esa es la tarea de la epistemología compleja.

A la hora de identificar posibles aplicaciones a los procesos investigativos, se debe tomar en cuenta que se trata de una propuesta con muy poco desarrollo metodológico todavía, tal como reconoce 
el mismo Morin; por lo tanto, aunque no existen pistas claras de cómo poner en uso aspectos como el principio de incertidumbre o la transdisciplinariedad, es posible ensayar algunos lineamientos generales. La primera pista consiste en la capacidad de integrar las teorías filosóficas, epistemológicas, éticas y científicas, una tarea muy urgente para la universidad actual, ya que esta se ha convertido en el preciso lugar donde ellas se divorcian y distancian.

Es muy frecuente en las ciencias humanas y sociales la actitud de permanente crítica hacia las ciencias duras o aplicadas respecto a sus carencias epistemológicas o filosóficas, porque en verdad suelen mirar con desdén tales interrogantes, sin conceder la posibilidad de beneficiarse del movimiento inverso que las obligaría a cuestionar sus propios logros desde las ciencias aplicadas en términos de mayor precisión, exactitud o pertinencia. Los ejercicios de inter o transdisciplinariedad implican no solo saltar los límites entre disciplinas emparentadas entre sí; también es necesario suturar linderos y fronteras más profundas como las que pueden existir entre la visión humanista y las ciencias. Se me ocurre, por ejemplo, que, al pretender investigar desde la botánica y la biología los principios activos de una planta y sus aplicaciones médicas, el cometido quedaría trunco, si no se incorpora la tradición oral y la mitología mediante las cuales las poblaciones locales codifican los conocimientos, significados y los usos en torno a dichos recursos. Sin duda alguna, investigaciones de este tipo implican trabajo en equipo y amplitud en la tarea de diseñar investigaciones.

En segundo lugar, el pensamiento complejo nos invita a no seccionar los objetos de conocimiento y mirarlos en su totalidad, tomando en cuenta los contextos que los soportan. Los problemas de investigación - cualquiera que ellos sean- se insertan en una situación, en un marco más amplio y forman parte de una totalidad que 
debe ser respetada y no mutilada por el enfoque investigativo, de tal modo que, si es necesario especificar y acotar el rango del estudio, siempre se debe partir del reconocimiento y respeto por la totalidad.

En tercer lugar, la apuesta de Morin nos invita a no idealizar, absolutizar o reificar las teorías, primero porque se trata de una entre tantas estrategias cognitivas; y luego, porque - como todo ser vivo- se degradan. Ello no es una invitación al relativismo indiscriminado y escéptico: su apuesta nos prohíbe vivir solo de la teoría y nos impele a considerarlas como sistemas abiertos y en constante transformación y a relacionarlas (en este sentido toda teoría es eminentemente relativa) con otras formas de conocimiento.

A la hora de la enseñanza o comprensión del patrimonio teórico de las ciencias, el pensamiento complejo propone la difícil tarea de no mirar tanto a los cúmulos conceptuales sino de penetrar en el núcleo paradigmático y en la lógica subyacente a cada propuesta teórica; es decir, nos obliga a priorizar el ámbito de la racionalidad antes que el de la racionalización. No se trata tanto de saber qué dijo tal o cual autor, ni de dedicar a la tarea exclusiva de develar los procedimientos lógicos de cada corriente cuanto de comprender cómo tal o cual autor pensó tal o cual problema, en términos de paradigmas o supuestos profundos de pensamiento; es decir, de penetrar no solamente los contenidos sino, y sobre todo, las maneras de pensar.

A pesar de los aportes señalados, planteamos dos posibles reparos a la propuesta de Morin que señaláramos en un artículo sobre el Buen Vivir, la relacionalidad y la disciplina en la educación superior (Juncosa, 2014, pp. 29-31). El primer reparo nace de la advertencia de Wallerstein respecto al resultado real de los esfuerzos para implementar la inter- y la transdisciplinariedad en las instituciones de conocimiento. Tales esfuerzos han cumplido la función de poner al día 
el ejercicio teórico de cara a las transformaciones científicas, fortaleciendo los aparatos organizativos en vez de abrir posibilidades para un mayor cuestionamiento de la razón de ser de las mismas disciplinas. En lugar de ello, se detonó el efecto contrario que sancionó la necesidad de la presencia de las disciplinas en el ámbito de otras en lugar de cuestionar su razón de ser. La disciplina, finalmente, llegó a ser tan importante que sin su aporte las demás no podrán sobrevivir, punto de vista de la actitud disciplinar identificado también por el filósofo afrocaribeño Lewis Gordon (2013). En palabras de Wallerstein,

[1]a alabanza de los méritos del trabajo interdisciplinario no ha minado hasta ahora significativamente la fuerza de los aparatos organizativos que amparan la separación existente entre las disciplinas. De hecho, casi se podría decir lo contrario: lo que ha acentuado la pretensión de cada disciplina de representar un ámbito coherente de análisis independiente vinculado a una metodología propia es la aseveración constante [...] de que cada una tiene algo que aprender de las otras [...] que este "otro" conocimiento es pertinente e importante para resolver los problemas intelectuales en los que cada una de esas disciplinas trabaja. El trabajo interdisciplinar no es en absoluto una crítica intelectual per se a la compartimentación actual de las ciencias sociales y en todo caso carece de influencia política para modificar las estructuras institucionales existentes. (Wallerstein, 2004, p. 136, citado en Juncosa, 2014, p. 30)

El segundo reparo al pensamiento complejo nace desde la opción por la interculturalidad crítica y consiste en el peligro de encerrar los "metapuntos de vista" en un circuito de autoobservación y acción autorreferida en el marco de conocimientos homogéneos propios de la ciencia. Así, para el pensamiento complejo el trabajo teórico corre el peligro de clausurarse en un ciclo de procesos cerrados que busca componer 


\section{6}

"teorías abiertas, racionales, críticas, reflexivas, autocríticas, aptas para auto-reformarse, auto-revolucionarse incluso" (Morin, 1998, p. 256), sin que requiera su conexión con los resurgimientos y la autoafirmación de los pueblos. En tanto proyecto que busca instaurar "una mejor manera de conocer" no por ello garantiza que las instituciones educativas, especialmente la universidad, se confronten a sí mismas respecto a los continuos posicionamientos de los pueblos indígenas y negros. No obstante, el pensamiento complejo admite una posibilidad si logra resignificar la transdisciplinariedad como articulación del pensamiento con los conocimientos otros, subalternizados y exteriorizados, para convertirlos en "metapuntos de vista" ineludibles capaces de confrontar la producción teórica con su carácter moderno colonial. (Juncosa, 2014, p. 30) 